\title{
Tectonic Record of Deformation in Intraplate Domains: Case Study of Far-Field Deformation in the Grands Causses Area, France
}

\author{
Oriane Parizot $\mathbb{D}$, Yves Missenard, Pierre Vergely, Frederic Haurine, Aurélie Noret, \\ Guillaume Delpech, Jocelyn Barbarand, and Philippe Sarda
}

Université Paris-Saclay, CNRS, GEOPS, 91405 Orsay, France

Correspondence should be addressed to Oriane Parizot; oriane.parizot@u-psud.fr

Received 7 October 2019; Revised 10 January 2020; Accepted 12 February 2020; Published 15 July 2020

Guest Editor: Enrique Gomez-Rivas

Copyright $\odot 2020$ Oriane Parizot et al. This is an open access article distributed under the Creative Commons Attribution License, which permits unrestricted use, distribution, and reproduction in any medium, provided the original work is properly cited.

\begin{abstract}
Although tectonic plates are usually considered as rigid blocks, intraplate deformation such as lithospheric buckling or diffuse brittle deformation has been recognized for a long time. However, the origin of these deformations remains puzzling. Indeed, whereas the chronology of deformation at plate boundaries can be constrained by numerous methods (syntectonic sedimentary record, thermochronology, etc.), dating of brittle structures (faults, veins, and joints) in the far-field domains remains challenging, preventing a global interpretation of the system as a whole. In this contribution, we have combined a tectonic study with a synkinematical geochronological study of fault-related calcites of the Grands Causses intraplate domain, north of the Pyrenean orogeny. We show that these faults record a much longer history of deformation than previously thought. The Mesozoic extension, usually attributed to an early Jurassic Tethysian rifting event, probably lasted until the Barremian-Aptian epoch, in response to the Pyrenean basin's opening. The so-called "Pyrenean deformation" of the Grands Causses domain, usually associated with the paroxysm of deformation in the belt during the late Eocene, began much earlier, around $100 \mathrm{Ma}$, and lasted for more than 60-70 Ma. This study demonstrates the high sensitivity of an intraplate domain (Grands Causses area) to record extensional or compressional deformations occurring at the edge of neighbouring plates.
\end{abstract}

\section{Introduction}

Tectonic inversion at plate boundaries has been known and studied since the beginning of the $20^{\text {th }}$ century, for example, through the studies of Lamplugh [1] and Stille [2], although the term "inversion" only appeared in the early 80s [3]. Since then, many other works have highlighted the widespread character of this phenomenon at plate boundaries, such as Williams et al. [4] or more recently Graveleau et al. [5].

However, the consequences of tectonic inversion at plate boundaries in the intraplate domain (far-field deformation) have not been studied as much. This deformation, several hundred kilometres away from the orogeny, is generally expressed by (1) kilometre scale denudation generally associated with lithospheric folding, (2) reactivations of crustal scale inherited faults, and (3) small-scale fracturing including low-displacement faults and tectonic joints sets-all of them being able to trigger, for instance, significant fluid flow and potential mineralization. These far-field phenomena have been characterized with numerical or analogue modelling or field studies (see examples in Cloetingh et al. [6], Gerbault et al. [7], or Sokoutis et al. [8] for lithospheric folding, Ziegler et al. [9] for intraplate fault reactivations, and Navabpour et al. [10] for small-scale fracturing), but the question of their age and the time relationships with the building of the orogen itself has remained puzzling. Lithospheric buckling relative dating can be asserted using analogue modelling. Fernández-Lozano et al. [11] showed that such long wavelength folding occurs in the early stages of basin inversion. Nonetheless, dating of crustal scale brittle deformations in the intraplate domain is still challenging, due to the lack of (1) syntectonic sedimentary records, in relation to very low displacements, and (2) adequate materials to be dated in the fault zones or joints. In the absence 
of such information, their age has been deduced by comparison with the generally well-constrained tectonic timeline of the adjacent domains based on stress orientation from the structure directions, on syntectonic sedimentary record, on thermochronology, etc. $[9,10]$ - a comparison that could in some cases lead to erroneous age attributions (see Parrish et al. [12]).

Our study questions the nature, origin, and age of intraplate deformations using the example of the Pyrenean belt and its repercussion in the far-field domain, north of the northern foreland basin (France). The studied area is located at the crossroads between several geodynamic areas with contrasting evolutions (Liguro-Provençal basin, Pyrenees, Massif Central, and Alps; Figures 1 and 2). We have focused on the Grands Causses area, $150 \mathrm{~km}$ north-east of the north Pyrenean frontal trust (NPFT; Figure 1). The contractional deformation of this area is usually associated with the Eocene Pyrenean tectonic pulse, although a syntectonic sedimentary record associated with these structures is lacking [13-16]. In the first part of this paper, the structural context of the Grands Causses domain has been highlighted. Then, we have detailed the petrographic and geochronological (U-Pb) results of synkinematical fault-related calcite analyses performed using High Resolution Inductively Coupled Plasma Mass Spectrometry coupled with a Laser Ablation System (LA-HR-ICPMS). Finally, we have proposed a global scenario linking intraplate fault activity/fluid circulations and plate geodynamics.

\section{Geological and Tectonic Setting}

\subsection{Overall Geodynamic Context}

2.1.1. Tethys Opening. From a geodynamic point of view, the dislocation of the Pangea that began in the Triassic period was at the origin of the opening from east to west of the Tethys Ocean in the south of France during the Jurassic period [17, 18]. The Liassic extension recorded in the Grands Causses domain is likely to be related to this general event at the scale of Western Europe. The dislocation of the Pangea induced the separation of two distinct continents: Gondwana in the south and Laurussia in the north, and an extensional synsedimentary phase on the southern margin of Western Europe, as evidenced by the presence of tilted blocks [19]. The subduction of this oceanic crust would be, during the Cenozoic period, at the origin of the collision of the Eurasian and Apulian plates, initiating the formation of the Alps chain.

2.1.2. Pyrenean History. The Pyrenean history follows a classical two-step scenario including the opening and later closure and inversion of basins [20-24].

First, the divergence of the Iberian/Eurasian plates induced an extensional phase and a crustal thinning from the late Jurassic to the early Cretaceous. This phase would be linked to a movement of Iberia towards the south-west of several hundred kilometres and is at the origin of a magma-poor hyperextended rift, the Pyrenean rift system [21, 25-33] (Figure 3). Then, according to paleomagnetic data, a counterclockwise rotation of the Iberian plate generated convergence between Iberian and Eurasian blocks, starting from the late Cretaceous [34]. This convergence induced basin inversion and continental collision in the Pyrenean domain.

The formation of the Pyrenean orogen is at the origin of many deformations of varying intensity depending on the distance from the chain [35]. In the inner Pyrenean belt, two deformation pulses have been identified [36]: the early stages of deformation occurred during the end of the late Cretaceous (Campanian-Maastrichtian; Figure 3) [37, 38]. The Paleocene was then marked by a slowdown in convergence related to the beginning of the continental collision $[38,39]$. The orogenic paroxysm has been dated between the Ypresian and the Bartonian linked to an acceleration in the convergence rate [40-42] (Figure 3). Thermochronology studies evidenced two cooling events confirming these two stages of contractional deformation (Campanian-Maastrichtian and Bartonian) and a denudation phase during the Oligocene period $[43,44]$.

In the foreland basins, the tectonic structures associated with the formation of the Pyrenean orogen are generally oriented east-west and derive from a stress field whose $\sigma 1$ is oriented north-south $[45,46]$. The age of the first deformations is younger than those recorded in the inner part of the belt according to some authors who have dated them as being early late Cretaceous (Cenomanian-Turonian) [47, 48] (Figure 3). In the Provence domain (Figure 1), the first deformations are dated from the Santonian to the Danian [49], as is the Aquitaine Basin, which underwent flexural deformation in the Maastrichtian [50]. Plaziat [40] highlighted a compressive phase in the Aquitaine Basin from the Ypresian to the Bartonian. Gély and Sztràkos [51] evidenced a $1^{\text {st }}$ phase of deformation associated with the flexuration of the Western European lithospheric plate during the Paleocene and then three successive tightening episodes during the Eocene (Figure 3). The recent study from Ortiz et al. [52] showed a paroxysm of shortening in the Aquitaine Basin during the Priabonian (35.8 Ma). The end of the Pyrenees shortening occurred during the Chattian (27.1 to $25.2 \mathrm{Ma})$ [52].

In the intraplate field, Briais et al. [53] highlighted two deformation phases in the Paris Basin associated with the convergence of the African and European plates during the Paleocene and the uppermost Ypresian. During the Paleocene, an exhumation phase has also been evidenced from a thermochronology study in the Morvan basin [54]. Parrish et al. [12] demonstrated intraplate deformation in Southern England during the Eocene based on $\mathrm{U}-\mathrm{Pb}$ dating of calcite veins (Figure 3).

2.1.3. Oligocene Rifting of the Liguro-Provençal Basin. Geodynamic history was thereafter marked by the opening of the Liguro-Provençal oceanic basin during the Oligocene period $[55,56]$. This extensional phase, associated with the northward movement of the African plate and the retreat of the subduction zone in the Mediterranean Sea, was at the origin of continental crust tearing in the back arc setting between Europe and the Corsica-Sardinia block [56, 57]. The 


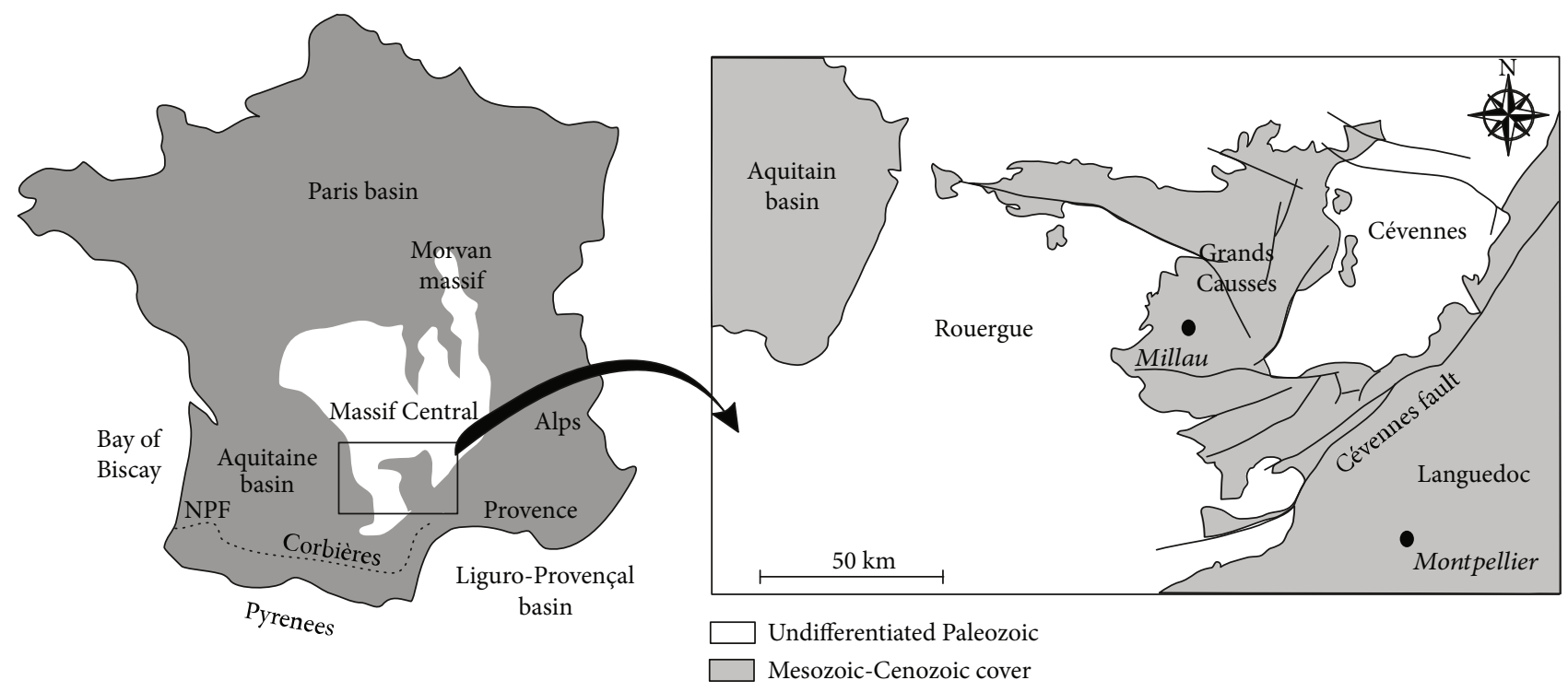

FIgURE 1: Localization of the studied area. NPFT: north Pyrenean frontal trust.

structural style associated with this geodynamic episode was strongly influenced by the Pyrenean orogen that caused lithospheric thickening in the area [58]. From a structural point of view, the Gulf of Lion margin is currently controlled by a subparallel NE-SW normal fault network and many small synrift basins such as the Alès basin [59] showing an extension towards the SE [60].

2.2. Geology of the Studied Area. The geological history of the Grands Causses area is strongly influenced by the larger scale Western Europe history presented above. During the Mesozoic, this area was indeed under the influence of the opening of the Tethys Ocean associated with the dislocation of Pangea. It then became part of the distant foreland basin (intraplate domain) of the Pyrenean orogen since its establishment. Finally, the Grands Causses area, due to this proximity to the Liguro-Provençal basin, became an area likely to be marked by the opening of the Gulf of Lion during the Cenozoic.

Paleozoic basement rocks outcrop in the Massif Central and delimit the Grands Causses area to the north, east, and west, while the south of the basin is separated from the Languedoc by the Cévennes fault network (Figures 1 and 2). Mesozoic sedimentation began in the Triassic period with a transgressive episode inducing a continental/marine transition and the formation of evaporites and marls [61]. The Jurassic limestones, clays, and dolostones demonstrate a marine depositional environment. Nowadays, these marine formations are outcropping at elevations between $800 \mathrm{~m}$ and $1000 \mathrm{~m}$ amsl and form vast plateaus deeply incised by the river network. Above the Jurassic limestones and dolostones, very scattered Cretaceous remnants testify to a later but poorly constrained sedimentation history [62].

From a tectonic point of view, several episodes have been evidenced during the history of the Grands Causses area from the Jurassic to the present [13-15], including extensional and compressional events. A first extensional event was at the origin of the formation of normal faults throughout the region during early Jurassic times. The Liassic age of this episode is well constrained due to the presence of kilometre-scale normal faults associated with progressive unconformity outcropping on the southern border of the Grands Causses domain [63-65]. The compressive tectonic structures of the Grands Causses domain (either neoformed or normal fault reactivation) have been related by previous authors to the nearby orogen, i.e., the Pyrenean orogen building during the Eocene period $[13,45,66]$. Finally, a late third geodynamic episode, again extensional, has been highlighted by some authors such as Macquar [15]. However, the Liassic progressive unconformities are the only reliable argument to attribute an age to deformation. So far, the ages of later event$s$-either extensional or compressional-have remained speculative due to the lack of post-Jurassic, potentially syntectonic, sedimentary records.

On a larger scale, vertical movements of the lithosphere deduced from the paleokarst studies of Camus [67], Bruxelles [68], and Husson [69] indicated (1) a regional uplift of the Grands Causses domain during the terminal early Cretaceous (>1600 $\mathrm{m}$ ) and (2) an uplift during the Miocene whose amplitude varied from a few metres to $400 \mathrm{~m}$. Thermochronological data from the Massif Central and the Grands Causses basin showed a significant exhumation episode (2000$2500 \mathrm{~m}$ of denudation) at the end of the early Cretaceous (110 Ma) suggesting erosion of a late Jurassic-early Cretaceous age sedimentary cover above the basement [70-72].

\section{Methodology}

3.1. Tectonics. Tectonic structures (fault planes, stylolithic peak axes, and tension joints) were measured over the entire Grands Causses area in the Jurassic cover over a surface area of $2500 \mathrm{~km}^{2}$, from Ste-Enimie to the north to Navacelles to the south, and from Sévérac-le-Château to the west to Florac to the east (Figure 2). They have been inversed using WinTensor software [73] in order to determine the paleostress field orientation using the right dihedral inversion method [74]. Field observations also allowed us to determine relative 


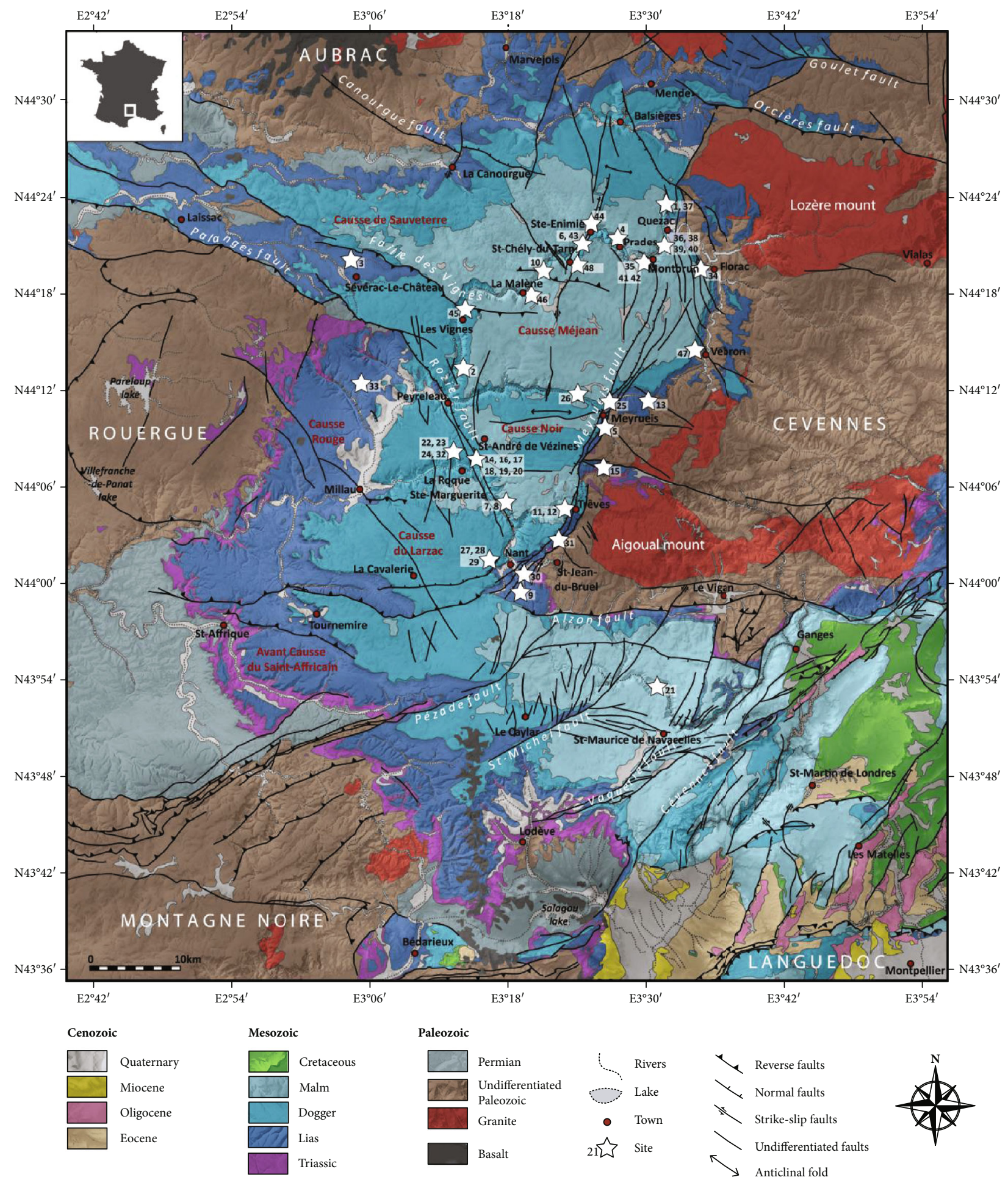

Figure 2: Structural scheme of the Grands Causses area. Modified after 1/50,000 geological maps [91-114]. See Table 1 for details about the studied sites.

chronology criteria in order to define the tectonic timeline in the Grands Causses area.

3.2. Analyses on Fault-Related Calcites. Our sampling strategy consisted of recovering synkinematic fault-related calcites that had undergone a relatively simple geological history, with a single deformation episode, in order to avoid multiple fluid circulation phases that could have induced a reopening of the isotopic system. For this reason, only calcites with a single family of slickensides were sampled for geochronological analyses.

3.2.1. Petrographic Observations. Calcite samples were analyzed in polished thin sections using optical microscopy in 


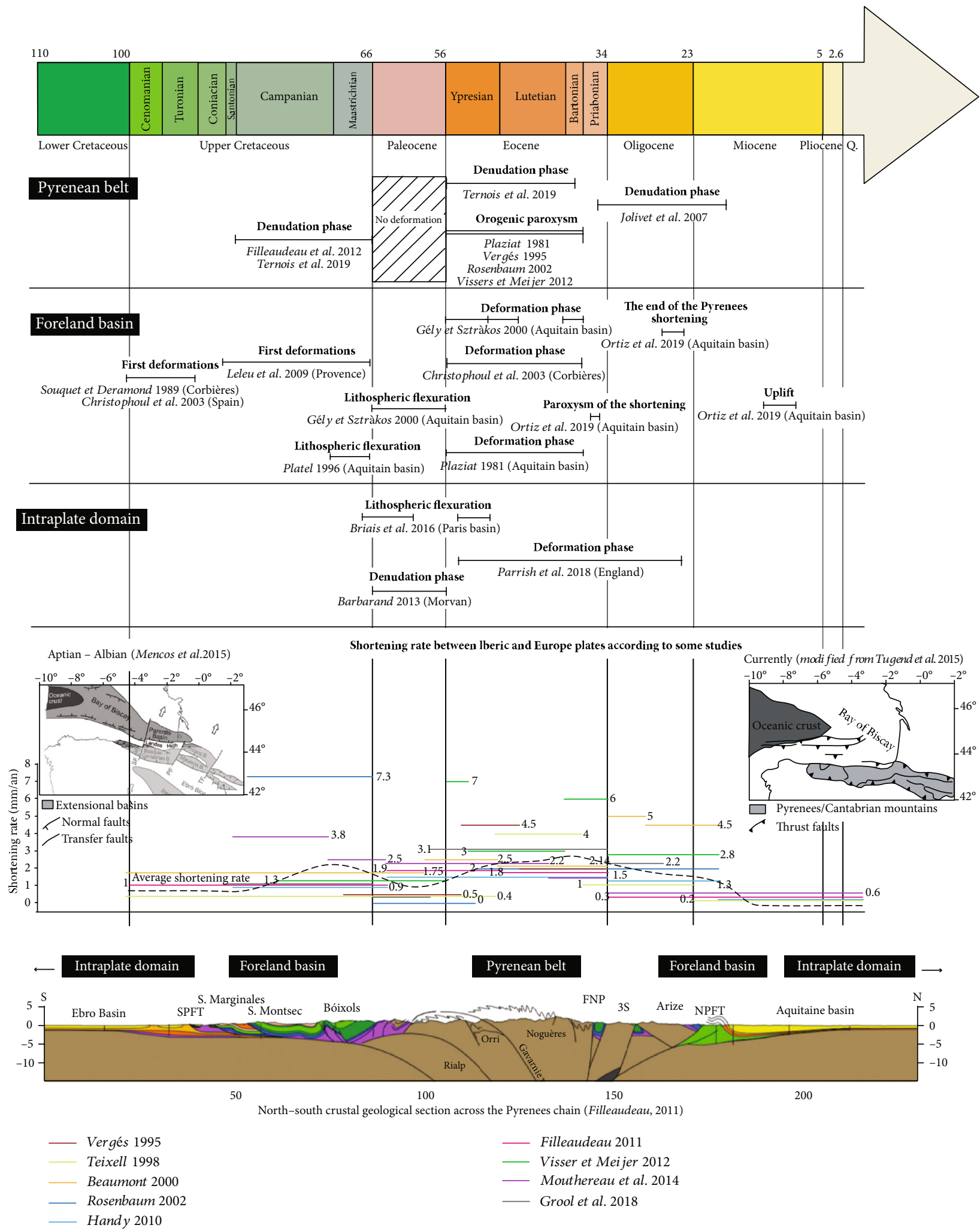

Figure 3: Summary of previous studies on the age of deformations related to the formation of the Pyrenees in various domains (orogenic belt, foreland basin, and intraplate domains) and on the rate of shortening between Iberia and European plates. While the deformation events at the plate boundary appear to be relatively short in time and correspond to high rates of shortening between both plates, the foreland basins show a continuous deformation from the upper Cretaceous to the Eocene [12, 37-44, 47-54, 88, 90, 115-118]. 
reflected and transmitted light and cathodoluminescence (CL). CL observations were carried out on an Olympus BX41 microscope (Olympus corporation, Tokyo, Japan) coupled to a cathodyne cold-cathode cathodoluminescence from NewTec (Nîmes, France) operating at $10 \mathrm{kV}$ and 200$300 \mu \mathrm{A}$ and a QICAM Fast 1394 digital camera (Teledyne QImaging, Surrey, Canada). The petrographic aim in this study was to highlight criteria for syndeformation fluid flow and to differentiate, as far as possible, the growth phases of calcitic minerals.

3.2.2. Calcite $U-P b$ Dating by LA-HR-ICPMS. U-Pb dating of some fault-related calcites by LA-HR-ICPMS was conducted using a High Resolution ICP-MS (Element XR from Thermo Scientific) coupled with a $193 \mathrm{~nm}$ ArF laser ablation system (Analyte Excite Excimer from Teledyne) at the GEOPS laboratory (Orsay, France). Since calcites commonly have low uranium concentrations and high common lead content, an elemental analysis of $\mathrm{U}$ and $\mathrm{Pb}$ was performed on a set of twenty-two samples in order to target samples with the highest $\mathrm{U}$ contents for $\mathrm{U}-\mathrm{Pb}$ dating.

The calcite dating was carried out on polished samples. The laser beam diameter was set to $150 \mu \mathrm{m}$, using a frequency of $8 \mathrm{~Hz}$ and a fluence of $4 \mathrm{~J} / \mathrm{cm}^{2}$. The analysis first consisted of the measurement of the background during 30 seconds before firing the laser for 30 seconds. Prior to U-Pb dating, a preablation was conducted at $155 \mu \mathrm{m}, 8 \mathrm{~Hz}$, and with a fluence of $4 \mathrm{~J} / \mathrm{cm}^{2}$ in order to reduce potential contamination. For each sample, 40 to 90 ablation spots were analyzed. The NIST614 glass standard was used for the ${ }^{207} \mathrm{~Pb} /{ }^{206} \mathrm{~Pb}$ calibration, and the WC-1 calcite was used for ${ }^{238} \mathrm{U} /{ }^{206} \mathrm{~Pb}$ calibration (254.4 $\pm 6.4 \mathrm{Ma}$; Roberts et al. [75]). Two secondary carbonate standards were also analyzed to validate the quality of the dating procedure (Duff Brown, $64.04 \pm 0.67 \mathrm{Ma}-$ dated using the isotope dilution method, Hill et al. [76]; B6, 42.99 $\pm 0.98 \mathrm{Ma}$-dated from LA-ICPMS, Pagel et al. [77]). The uncertainties in brackets correspond to the propagated uncertainties (see Supplementary Materials for analytical details (available here)). Signals were processed with Iolite (C) software [78], and ages were obtained from the conventional Tera-Wasserburg diagram [79] using Isoplot@ software [80]. Details on the method can be found in the Supplementary Materials.

\section{Results}

\subsection{Tectonics}

4.1.1. Stress Tensors. Almost 800 tectonic structures have been measured in the Grands Causses area (Figures 4-6, Table 1). Generally, extensional structures in this area corresponded to normal faults (Figure 4(a)) identified from tectoglyphs (slickensides on fault-related calcite) on fault mirrors or stratigraphic shifts. Compressive deformation had a much more varied range of tectonic structures: field observations showed the presence of reverse and strike-slip metric faults but also of folds with an east-west axis (Figure 4(b)). The tectoglyphs were also diverse: fault-related calcite, grooves, mechanical slickensides, stylolithic peaks, and secondary fault planes (Figures 4(c)-4(f)).

Stress tensors resulting from the inversion of extensional structures revealed various orientations of the stress field (Figure 5, blue lines). The variation of the stress field existed at the regional level (for instance, on site " 33 " - in the west of the studied area, north of Millau-the $\sigma 3$ orientation is WNW-ESE compared to site "10"-north of the Causse Méjean, in the north of the studied area-the $\sigma 3$ orientation is NE-SW (Figure 5)). These variations also existed at the local level (there were, for example, two different orientations of the stress field on sites "9" $(\sigma 3 \sim \mathrm{NW}-\mathrm{SE}$ and NNE-SSW)-south-east of the Causse du Larzac, in the south of the studied area-and " 31 " $(\sigma 3 \sim \mathrm{NE}-\mathrm{SW}$ and NW-SE) - in the east of the Causse du Larzac, north of St-Jean-du-Bruel).

Conversely, reverse and strike-slip fault inversion gave relatively uniform results (Figure 5, red lines). Indeed, the inversion of nearly 400 microtectonic data (corresponding mainly to fault plane measurements) showed a generally homogeneous N-S shortening direction at the outcrop level as well as at the regional level.

4.1.2. Relative Chronology. The overlap of tectonic structures was observed at the outcrop scale (relative chronology between structures) as well as at the fault mirror scale (superposition of slickensides with different orientations). We evidenced an early extensional episode whose stress field orientation had not been determined precisely because of the small number of fault mirrors on which this relative chronology was observed (Figure 6). The Grands Causses area was subsequently affected by a compressive regime that was responsible for the formation of a large network of reverse and strike-slip (sinistral and dextral) faults with $\sigma 1$ generally oriented north-south (Figures 5 and 6). In the area, some of the reverse faults overlap strike-slip faults (Figure 6). However, due to a lack of microstructural data, it was difficult to accurately determine the relative chronology of these tectonic structures. Based on previous studies $[13,15,46]$ and the homogeneity of the stress field throughout the Grands Causses region, we believe here that both strike-slip and reverse structures are associated with a single deformation episode. Finally, a last extensional episode was observed since some strike-slip faults were crosscut by normal faults (Figure 6). This last relative chronology highlighted an extensional episode associated with a $\sigma 3$ orientation roughly NW-SE (based on only three measurements).

4.2. Petrographic Observations. Optical microscopic observation of fault-related calcites showed the presence of various markers of syndeformation crystallization, such as the inclusion trails (parallel to the surface of the host rock) and inclusion bands (oblique to the surface of the host rock) highlighted by Ramsay and Huber [81], Koehn and Passchier [82], Fagereng et al. [83], and Bons et al. [84] (Figure 7). The texture of calcites varied from one sample to another as well as within a sample. Indeed, fault-related calcites may be composed of rounded grains and elongated 


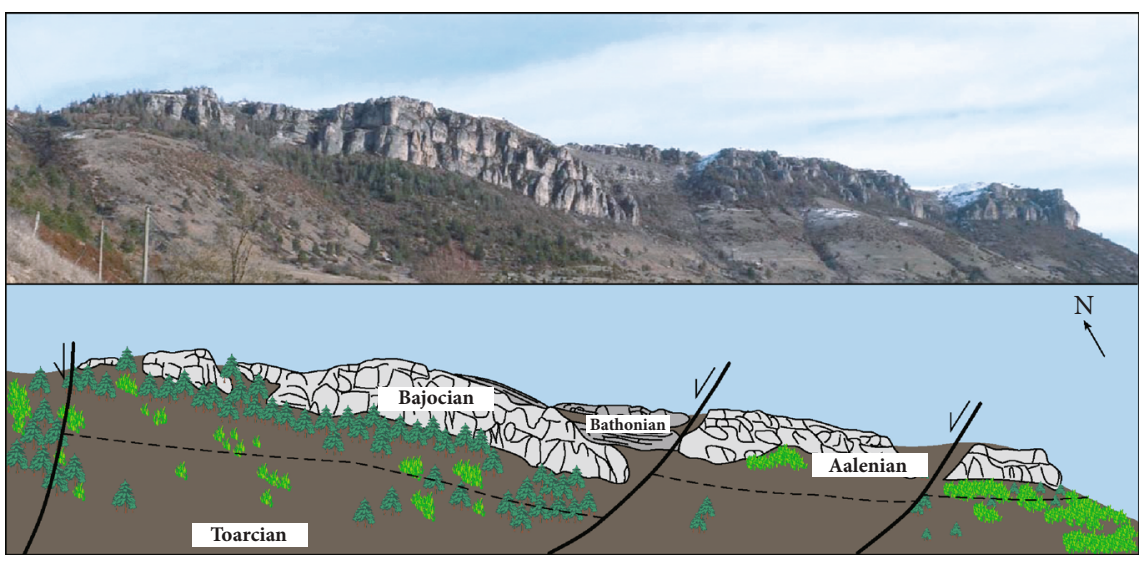

(a)

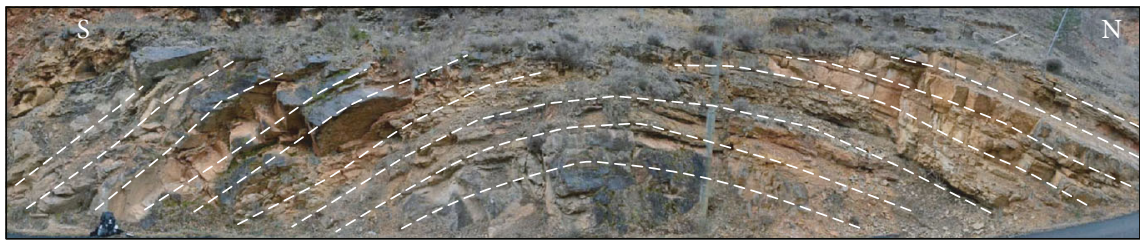

(b)

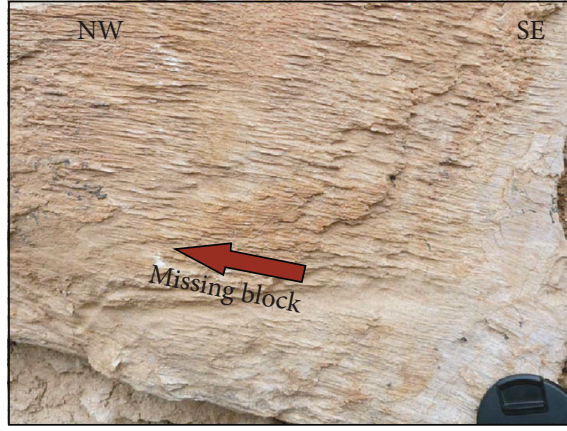

(c)

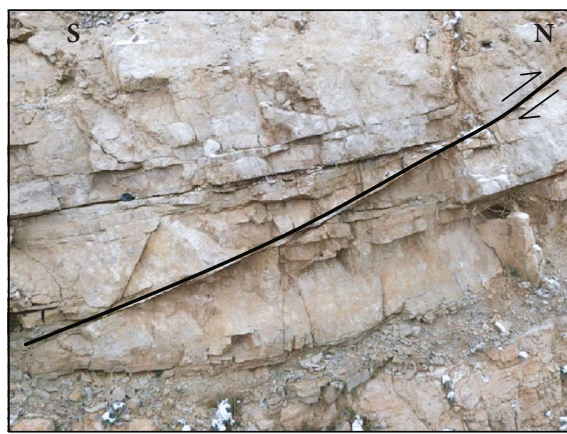

(e)

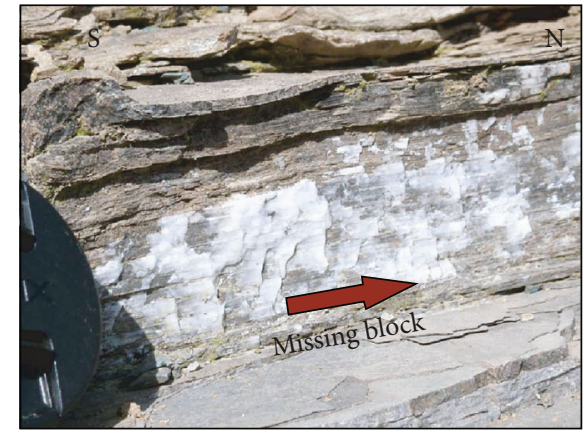

(d)

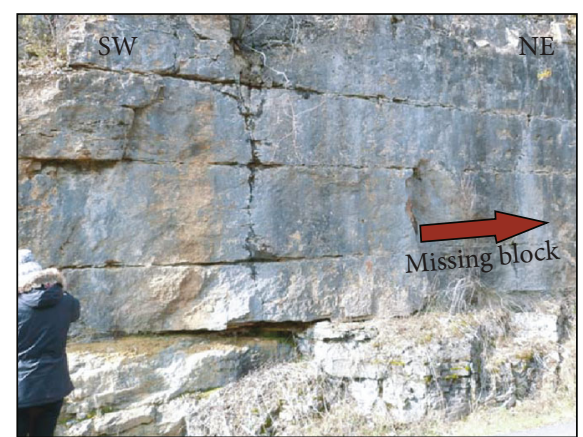

(f)

Figure 4: Examples of tectonic structures of the Grands Causses area. (a) Regional-scale Meyrueis normal fault network (Figure 2, $\left.\mathrm{N} 44^{\circ} 12^{\prime}-\mathrm{E} 3^{\circ} 25^{\prime}\right)$. (b) East-west fold associated with north-south compression. (c, d) Tectoglyphs on fault mirror ((c) stylolithic peaks; (d) slickenfibres on a fault plane). (e, f) Fault planes at outcrop scale ((e) reverse fault; (f) strike-slip fault).

grains (with the axis of the elongation inclined to the host rock) as well as fibers (parallel to the host rock) (Figure 7).

Cathodoluminescence microscopy showed (1) a varying degree of luminescence from one fault-related calcite to another, unrelated to the nature of the fault: cathodoluminescence observations showed a dull-orange color for
CA18J06-1 sample and brown for CA18J05-1 sample (Figures 7(c) and 7(d)); (2) a luminescence of fault-related calcites which was relatively uniform across the samples except at the location of some rounded grains which showed growth zonations alternating from bright to nonluminescent (Figure 7(b)). 


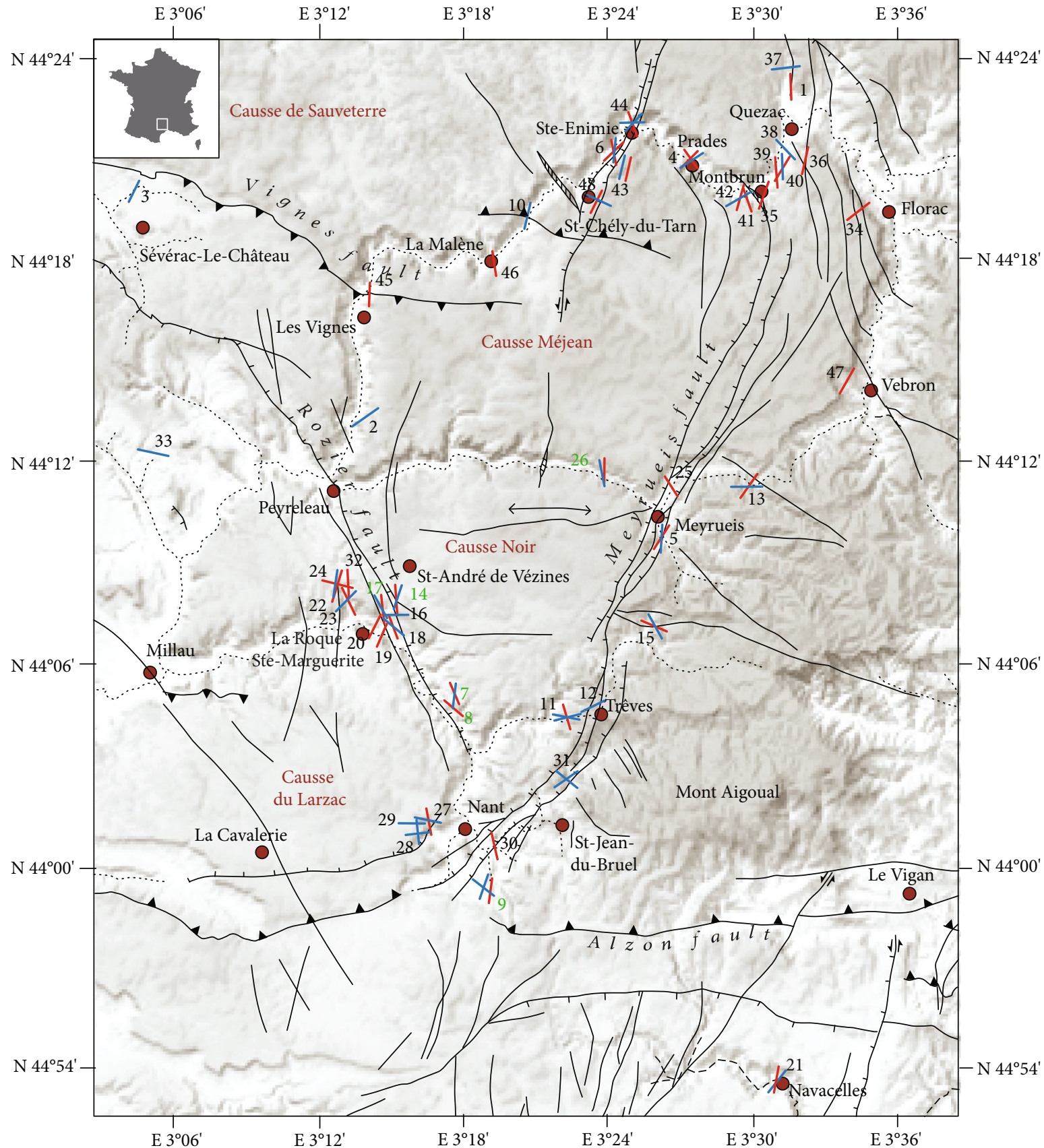

13 Site 9 Site with dated sample

$$
\begin{aligned}
& \text { Compressive regime: } \\
& \sigma 1 \text { main stress orientation } \\
& \text { | Extensional regime: } \\
& \sigma 3 \text { main stress orientation } \\
& \text { ○ Town }
\end{aligned}
$$

FIGURE 5: Results of microtectonic data inversion in the studied area using the WinTensor program [73]. The inversion results are represented by lines corresponding to the orientation of the main stresses: for compressive regimes, the red lines are associated with the orientation of $\sigma 1$; for extensional regimes, the blue lines are associated with the orientation of $\sigma 3$. See Tables 1 and 2 for details about sites and dated samples and see text for discussion.

4.3. $\mathrm{U}-\mathrm{Pb}$ Dating. U-Pb data with $2 \sigma$ errors are compiled in Figure 8 . The uncertainties in brackets correspond to the propagated uncertainties. Among the selected samples, only $1 / 3$ could be dated because of the high common lead content and the low amount of uranium in the samples (Table 2). Regarding the dating of secondary standards in this study, Duff Brown was dated at $62.8 \pm 2.1 \mathrm{Ma}(\mathrm{MSWD}=4.5)$ and $\mathrm{B} 6$ at $41.52 \pm 0.63 \mathrm{Ma}(\mathrm{MSWD}=1.8)$ (Figures $8(\mathrm{a})$ and 


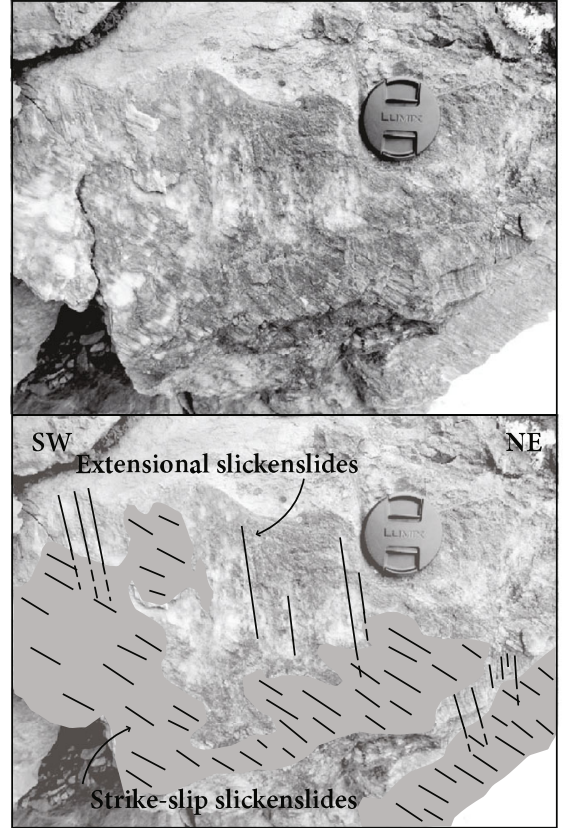

(a)

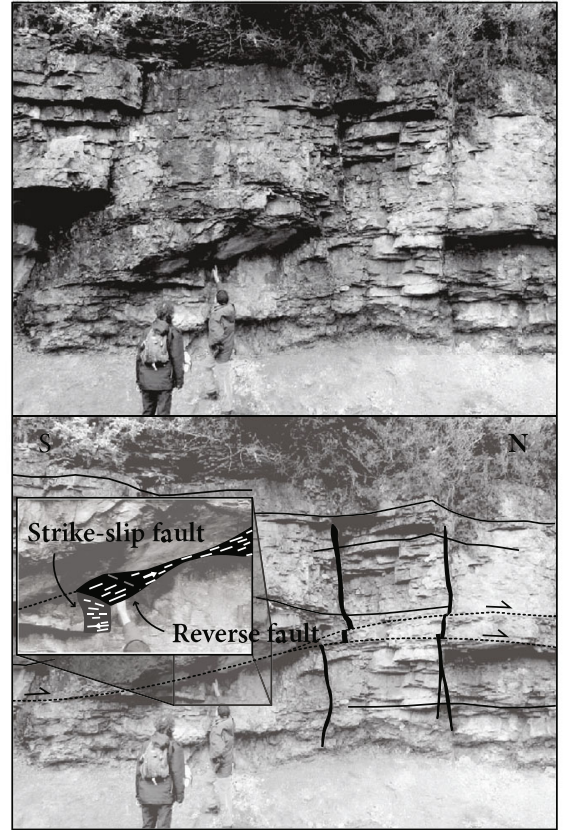

(b)

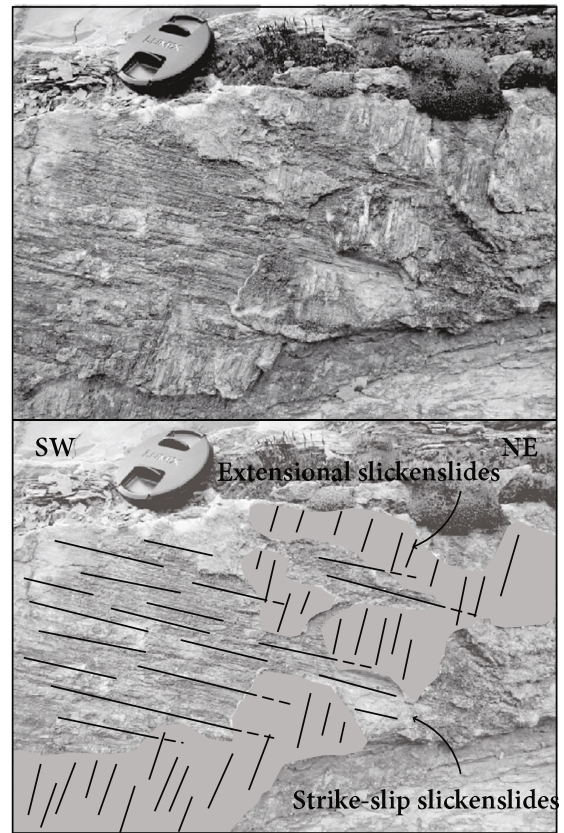

(c)

Geodynamic episodes since Jurassic
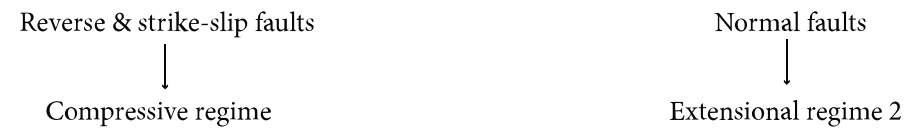

FIGURE 6: Tectonic structures showing relative chronology between deformation episodes. (a) This illustration shows an extensional regime intersected by a strike-slip regime on a fault mirror. (b) A reverse fault observed at the scale of the outcrop shifts a dextral strike-slip fault plane. (c) Slickenside normal fault-related calcites overlapped by strike-slip slickenside calcites.

8(b)). Normal fault-related calcite CA18J03-1 was dated at $128 \pm 15$ [15.4] Ma with a MSWD of 1.5 (Figure 8(c)). For strike-slip fault-related calcites, CA18J09-4 was dated at $107 \pm 13$ [13.3] Ma (MSWD = 3.9), CA18J03-2 was dated at $38.7 \pm 6.7[6.8] \mathrm{Ma}(\mathrm{MSWD}=0.75)$, and NAV01 at $36.5 \pm$ 7.7 [7.8] Ma (Figures 8(d), 8(h), and 8(i)). For reverse faultrelated calcites, an age of $79.1 \pm 7.6[7.9] \mathrm{Ma}(\mathrm{MSWD}=1.6)$ was obtained for CA18J05-1, of $95 \pm 15$ [15.2] Ma $(\mathrm{MSWD}=1.4)$ for CA18J06-1, and of $58.2 \pm 4.6$ [4.9] Ma $(\mathrm{MSWD}=0.72)$ for CA18J03-4 (Figures $8(\mathrm{e})-8(\mathrm{~g})$ ).

\section{Discussion}

5.1. Characteristics of the Fault-Related Calcites. The intraplate deformation of the Grands Causses area has been characterized from the observation and analysis of tectonic structures that have undergone, one by one, a relatively simple geological history. In fact, the choice to consider small, only metric-sized, structures and to analyze singlephase fault-related calcites was aimed at reducing the risk of reopening geochemical systems, which may have led to results that would not have been representative of the considered tectonic phase.

Some previous studies have focused on the morphology, petrography, and growth of fault-related calcites (slickenfibre calcite), highlighting some criteria of syndeformation such as inclusion bands and inclusion trails and the growth direction of elongated grains associated with the $\sigma 1$ main stress [8187]. Bons et al. [84] described inclusion bands as "arrays of wall-rock inclusions, dust, secondary minerals or fluid inclusions that were included or precipitated at the vein growth front." Inclusion trails corresponded to arrays of inclusions which were "assumed to follow the opening trajectory of a vein" [82]. Although these two types of morphology associated with fault-related calcites may allow us to determine the history of the opening of the slickenfibre calcite, their interpretation is often not straightforward [82].

In this study, the petrography of the fault-related calcites confirms the syntectonic character of their crystallization due to the presence of these criteria (Figure 7). Moreover, cathodoluminescence observations showed that the studied objects crystallized during a single growth phase, except for some zones associated with rounded grains that may have growth zonations.

\subsection{Unraveling the Complexity of the Extensional Footprint.} Fieldwork showed that the formation of some of the normal faults occurred prior to the compressive episode which was associated with the Pyrenean phase and with the northward movement of Africa according to some authors such as 
TABLE 1: Detailed information for microtectonic sites. See Figure 2 for the location of sites and Table 2 for more details about dated samples. The orientation of the main stress is specified in brackets when two stress regimes are identified for the same site.

\begin{tabular}{|c|c|c|c|c|c|c|}
\hline \multirow{2}{*}{ Site } & \multirow{2}{*}{ GPS coordinates } & \multirow{2}{*}{ Stratigraphy } & \multirow{2}{*}{ Lithology } & \multicolumn{2}{|c|}{ Number of analyses/stress regime } & \multirow{2}{*}{ Dated sample } \\
\hline & & & & Compressive & Extensive & \\
\hline 1 & $44^{\circ} 22.625^{\prime} \mathrm{N} 3^{\circ} 31.280^{\prime} \mathrm{E}$ & Bajocian & Dolostone & 8 & & \\
\hline 2 & $44^{\circ} 13.368^{\prime} \mathrm{N} 3^{\circ} 13.459^{\prime} \mathrm{E}$ & Bajocian & Limestone/dolostone & & 1 & \\
\hline 3 & $44^{\circ} 20.303^{\prime} \mathrm{N} 3^{\circ} 4.066^{\prime} \mathrm{E}$ & Hettangian & Dolostone & & 26 & \\
\hline 4 & $44^{\circ} 21.292^{\prime} \mathrm{N} 3^{\circ} 27.674^{\prime} \mathrm{E}$ & Bathonian & Dolostone & $\begin{array}{c}15 \text { ( } \sigma 1 \mathrm{NW}-\mathrm{NE}) \\
6 \text { ( } \sigma 1 \mathrm{NE}-\mathrm{SW})\end{array}$ & 15 & \\
\hline 5 & $44^{\circ} 10.291^{\prime} \mathrm{N} 3^{\circ} 25.871^{\prime} \mathrm{E}$ & Hettangian & Limestone/dolostone & 8 & 22 & \\
\hline 6 & $44^{\circ} 21.235^{\prime} \mathrm{N} 3^{\circ} 23.966^{\prime} \mathrm{E}$ & Bathonian & Dolostone & $\begin{array}{c}8(\sigma 1 \mathrm{~N}-S) \\
4(\sigma 1 \mathrm{NE}-\mathrm{SW})\end{array}$ & 6 & \\
\hline 7 & $44^{\circ} 5.247^{\prime} \mathrm{N} 3^{\circ} 17.413^{\prime} \mathrm{E}$ & Kimmeridgian & Limestone & 3 & 8 & CA18J03-1 \\
\hline 8 & $44^{\circ} 4.788^{\prime} \mathrm{N} 3^{\circ} 16.983^{\prime} \mathrm{E}$ & Bathonian & Limestone & 12 & & CA18J03-2 \\
\hline 9 & $43^{\circ} 59.758^{\prime} \mathrm{N} 3^{\circ} 18.772^{\prime} \mathrm{E}$ & Hettangian & Limestone/dolostone & 9 & $\begin{array}{c}10(\sigma 3 \mathrm{NW}-\mathrm{SE}) \\
25(\sigma 3 \mathrm{~N}-\mathrm{S})\end{array}$ & CA18J03-4 \\
\hline 10 & $44^{\circ} 20.046^{\prime} \mathrm{N} 3^{\circ} 21.252^{\prime} \mathrm{E}$ & Kimmeridgian & Limestone & & 5 & \\
\hline 11 & $44^{\circ} 4.731^{\prime} \mathrm{N} 3^{\circ} 22.398^{\prime} \mathrm{E}$ & Oxfordian & Limestone & 11 & $\begin{array}{c}29 \text { ( } \sigma 3 \text { ENE-WSW); } \\
7 \text { ( } \sigma 3 \text { ESE-WNW })\end{array}$ & \\
\hline 12 & $44^{\circ} 4.849^{\prime} \mathrm{N} 3^{\circ} 23.062^{\prime} \mathrm{E}$ & Oxfordian & Limestone & & 2 & \\
\hline 13 & $44^{\circ} 11.981^{\prime} \mathrm{N} 3^{\circ} 29.092^{\prime} \mathrm{E}$ & Hettangian & Dolostone & 7 & 3 & \\
\hline 14 & $44^{\circ} 7.968^{\prime} \mathrm{N} 3^{\circ} 15.050^{\prime} \mathrm{E}$ & Bathonian & Limestone & 5 & 7 & CA18J05-1 \\
\hline 15 & $44^{\circ} 7.516^{\prime} \mathrm{N} 3^{\circ} 24.675^{\prime} \mathrm{E}$ & Hettangian & Dolostone & 4 & 9 & \\
\hline 16 & $44^{\circ} 7.709^{\prime} \mathrm{N} 3^{\circ} 14.880^{\prime} \mathrm{E}$ & Bathonian & Limestone/dolostone & & 8 & \\
\hline 17 & $44^{\circ} 7.792^{\prime} \mathrm{N} 3^{\circ} 14.643^{\prime} \mathrm{E}$ & Bathonian & Limestone/dolostone & 10 & 1 & CA18J06-1 \\
\hline 18 & $44^{\circ} 7.541^{\prime} \mathrm{N} 3^{\circ} 14.561^{\prime} \mathrm{E}$ & Bathonian & Limestone/dolostone & 8 & 7 & \\
\hline 19 & $44^{\circ} 7.477^{\prime} \mathrm{N} 3^{\circ} 14.531^{\prime} \mathrm{E}$ & Bathonian & Limestone/dolostone & 7 & & \\
\hline 20 & $44^{\circ} 7.408^{\prime} \mathrm{N} 3^{\circ} 14.556^{\prime} \mathrm{E}$ & Bathonian & Limestone/dolostone & 10 & & \\
\hline 21 & $43^{\circ} 53.739^{\prime} \mathrm{N} 3^{\circ} 30.172^{\prime} \mathrm{E}$ & Oxfordian & Limestone & 22 & 13 & NAV01 \\
\hline 22 & $44^{\circ} 8.175^{\prime} \mathrm{N} 3^{\circ} 13.044^{\prime} \mathrm{E}$ & Bathonian & Limestone & & 6 & \\
\hline 23 & $44^{\circ} 8.308^{\prime} \mathrm{N} 3^{\circ} 13.052^{\prime} \mathrm{E}$ & Bathonian & Limestone & 3 & & \\
\hline 24 & $44^{\circ} 8.570^{\prime} \mathrm{N} 3^{\circ} 12.953^{\prime} \mathrm{E}$ & Bathonian & Limestone & $\begin{array}{c}8(\sigma 1 \mathrm{E}-\mathrm{W}) ; \\
1(\sigma 1 \mathrm{NE}-\mathrm{SW})\end{array}$ & 12 & \\
\hline 25 & $44^{\circ} 11.623^{\prime} \mathrm{N} 3^{\circ} 26.465^{\prime} \mathrm{E}$ & Hettangian & Limestone/dolostone & 16 & & \\
\hline 26 & $44^{\circ} 11.970^{\prime} \mathrm{N} 3^{\circ} 23.942^{\prime} \mathrm{E}$ & Oxfordian & Limestone & 24 & 6 & CA18J09-4 \\
\hline 27 & $44^{\circ} 1.364^{\prime} \mathrm{N} 3^{\circ} 16.591^{\prime} \mathrm{E}$ & Bajocian & Limestone & 10 & 3 & \\
\hline 28 & $44^{\circ} 1.485^{\prime} \mathrm{N} 3^{\circ} 16.125^{\prime} \mathrm{E}$ & Bajocian & Limestone & & $\begin{array}{c}4(\sigma 3 \mathrm{~N}-\mathrm{S}) \\
16(\sigma 3 \mathrm{E}-\mathrm{W})\end{array}$ & \\
\hline 29 & $44^{\circ} 1.460^{\prime} \mathrm{N} 3^{\circ} 16.310^{\prime} \mathrm{E}$ & Bajocian & Limestone & & 26 & \\
\hline 30 & $44^{\circ} 0.773^{\prime} \mathrm{N} 3^{\circ} 18.932^{\prime} \mathrm{E}$ & Hettangian & Dolostone & 5 & & \\
\hline 31 & $44^{\circ} 2.891^{\prime} \mathrm{N} 3^{\circ} 22.324^{\prime} \mathrm{E}$ & Hettangian & Dolostone & & $\begin{array}{l}18 \text { ( } \sigma 3 \mathrm{NW}-\mathrm{SE}) \\
13 \text { ( } \sigma 3 \mathrm{NE}-\mathrm{SW})\end{array}$ & \\
\hline 32 & $44^{\circ} 8.706^{\prime} \mathrm{N} 3^{\circ} 13.017^{\prime} \mathrm{E}$ & Bathonian & Limestone & 22 & & \\
\hline 33 & $44^{\circ} 12.426^{\prime} \mathrm{N} 3^{\circ} 4.845^{\prime} \mathrm{E}$ & Hettangian & Limestone/dolostone & & 83 & \\
\hline 34 & $44^{\circ} 19.775^{\prime} \mathrm{N} 3^{\circ} 34.305^{\prime} \mathrm{E}$ & Oxfordian & Limestone & 9 & & \\
\hline 35 & $44^{\circ} 20.004^{\prime} \mathrm{N} 3^{\circ} 30.454^{\prime} \mathrm{E}$ & Kimmeridgian & Limestone & 26 & & \\
\hline 36 & $44^{\circ} 21.282^{\prime} \mathrm{N}^{\circ} 32.099^{\prime} \mathrm{E}$ & Oxfordian & Limestone & 4 & & \\
\hline 37 & $44^{\circ} 24.007^{\prime} \mathrm{N} 3^{\circ} 31.152^{\prime} \mathrm{E}$ & Oxfordian & Limestone & & 19 & \\
\hline 38 & $44^{\circ} 21.453^{\prime} \mathrm{N} 3^{\circ} 31.243^{\prime} \mathrm{E}$ & Oxfordian & Limestone & & 2 & \\
\hline
\end{tabular}


TABLE 1: Continued.

\begin{tabular}{|c|c|c|c|c|c|c|}
\hline \multirow{2}{*}{ Site } & \multirow{2}{*}{ GPS coordinates } & \multirow{2}{*}{ Stratigraphy } & \multirow{2}{*}{ Lithology } & \multicolumn{2}{|c|}{ Number of analyses/stress regime } & \multirow{2}{*}{ Dated sample } \\
\hline & & & & Compressive & Extensive & \\
\hline 39 & $44^{\circ} 21.052^{\prime} \mathrm{N}^{\circ} 31.084^{\prime} \mathrm{E}$ & Bajocian & Dolostone & 10 & 5 & \\
\hline 40 & $44^{\circ} 20.861^{\prime} \mathrm{N} 3^{\circ} 30.736^{\prime} \mathrm{E}$ & Bathonian & Dolostone & 3 & & \\
\hline 41 & $44^{\circ} 20.238^{\prime} \mathrm{N} 3^{\circ} 29.548^{\prime} \mathrm{E}$ & Oxfordian & Limestone & 15 & & \\
\hline 42 & $44^{\circ} 20.209^{\prime} \mathrm{N} 3^{\circ} 29.316^{\prime} \mathrm{E}$ & Kimmeridgian & Limestone & 3 & 14 & \\
\hline 43 & $44^{\circ} 21.228^{\prime} \mathrm{N} 3^{\circ} 24.122^{\prime} \mathrm{E}$ & Oxfordian & Limestone & 20 & 8 & \\
\hline 44 & $44^{\circ} 22.359^{\prime} \mathrm{N} 3^{\circ} 24.741^{\prime} \mathrm{E}$ & Oxfordian & Limestone & 12 & $\begin{array}{c}6(\sigma 3 \mathrm{E}-\mathrm{W}) \\
3(\sigma 3 \mathrm{NE}-\mathrm{SW})\end{array}$ & \\
\hline 45 & $44^{\circ} 17.155^{\prime} \mathrm{N} 3^{\circ} 13.983^{\prime} \mathrm{E}$ & Bathonian & Dolostone & 14 & & \\
\hline 46 & $44^{\circ} 17.967^{\prime} \mathrm{N}^{\circ} 19.508^{\prime} \mathrm{E}$ & Kimmeridgian & Limestone & 14 & & \\
\hline 47 & $44^{\circ} 14.442^{\prime} \mathrm{N} 3^{\circ} 33.772^{\prime} \mathrm{E}$ & Hettangian & Dolostone & 9 & & \\
\hline 48 & $44^{\circ} 19.942^{\prime} \mathrm{N} 3^{\circ} 23.364^{\prime} \mathrm{E}$ & Kimmeridgian & Limestone & 11 & 12 & \\
\hline
\end{tabular}

Macquar [15], De Charpal et al. [14], and Constantin et al. [13] (Figure 6). According to this latter, the extension record of the whole area was mainly Jurassic in age as a consequence of the Tethys Ocean opening. This geodynamic event was highlighted in the literature by progressive unconformity outcropping $[63,64]$.

In this study, the $\mathrm{U}-\mathrm{Pb}$ results show that some normal faults of the Grands Causses area resulted from a much later extension, most likely at the early Cretaceous in age (Barremien; Figure $8(\mathrm{c})$ ), relatively simultaneous to the opening of the Pyrenean basins to the south [24]. In addition, the normal fault CA18J03-1 $(128 \pm 15$ [15.4] Ma) is related to a NNE-SSW extension. By extrapolating this $\mathrm{U}-\mathrm{Pb}$ age to the other normal faults of this family, the Cretaceous extension would therefore correspond to a stress field such as $\sigma 3$ which is approximately oriented N-S (Figure 5). This result is consistent with the geometry of the Pyrenean basin opening [88, 89] (Figure 3). Consequently, the Mesozoic extension in the Grands Causses domain probably lasted much longer than previously proposed in response to farfield stress transmission either related to the Tethys or Pyrenean basin opening episodes.

In summary, we provide new evidence that the Grands Causses domain underwent two different extensional events during Mesozoic times: a first one during the Jurassic in response to the Tethys basin opening and a second one during the early Cretaceous as a consequence of Pyrenean basins opening along a N-S direction. The transition between both events may have been gradual, implying that the Grands Causses domain has been subjected to a longlived extension episode since the Lias to the early Cretaceous in response to plate boundaries' deformation. Moreover, based on the overlap of normal slickensides above strikeslip slickensides (Figure 6), a late extensional geodynamic episode was recorded in the Grands Causses area after the Pyrenean compressive episode (see discussion in the next section). Although no calcite related to these faults was dated, this episode could be interpreted as a consequence of the opening of the Liguro-Provençal basin during Oligo- cene times [46]. The NW-SE orientation of the stress field associated with these structures is indeed consistent with this geodynamic episode [56].

Concerning the stress field associated with the extension in the Grands Causses area, the microtectonic data showed a significant heterogeneity of its orientation (Figure 5). The early extension during the Cretaceous could be associated with a stress field with $\sigma 3$ north-south while the late extension to the Cenozoic could come from a stress field $\sigma 3$ NW-SE. However, this heterogeneity in the set of stress tensors can be explained by (1) a superposition of several deformation episodes since the Mesozoic, (2) the compaction of formations at the origin of extensional structures without preferential orientation, and (3) fault planes formed from preexisting planes (fractures, reverse, and strike-slip fault planes for late extension).

5.3. So-Called "Pyrenean Deformation" of the Grands Causses Domain. The Grands Causses area is characterized by many reverse and strike-slip fault planes resulting from a rather homogeneous stress field with a N-S shortening orientation (Figure 5). These compressive structures are usually considered as contemporaneous with the Pyrenean belt building during Eocene times $[13,14]$, but it remains a purely speculative affirmation in the absence of a syntectonic sedimentary record.

The U-Pb ages have shed a new light on this commonly accepted idea. Indeed, although the age uncertainties are relatively high $(2 \sigma \sim 15 \%$, Figure 8$)$ due to low uranium content and the relative abundance of common lead in calcites, the $\mathrm{U}-\mathrm{Pb}$ ages showed the record of a continuous brittle deformation over several tens of millions of years, from Albian to Priabonian times (older age: $107 \pm 13$ [13.3] Ma; younger age: $36.5 \pm 7.7$ [7.8] Ma). This indicates that the intraplate brittle deformation that occurred in response to basin closure at the Iberia/Europe plate boundary lasted much longer than previously thought and is not simply the record of the paroxysmal phases of mountain building of the terminal Eocene age [45]. 


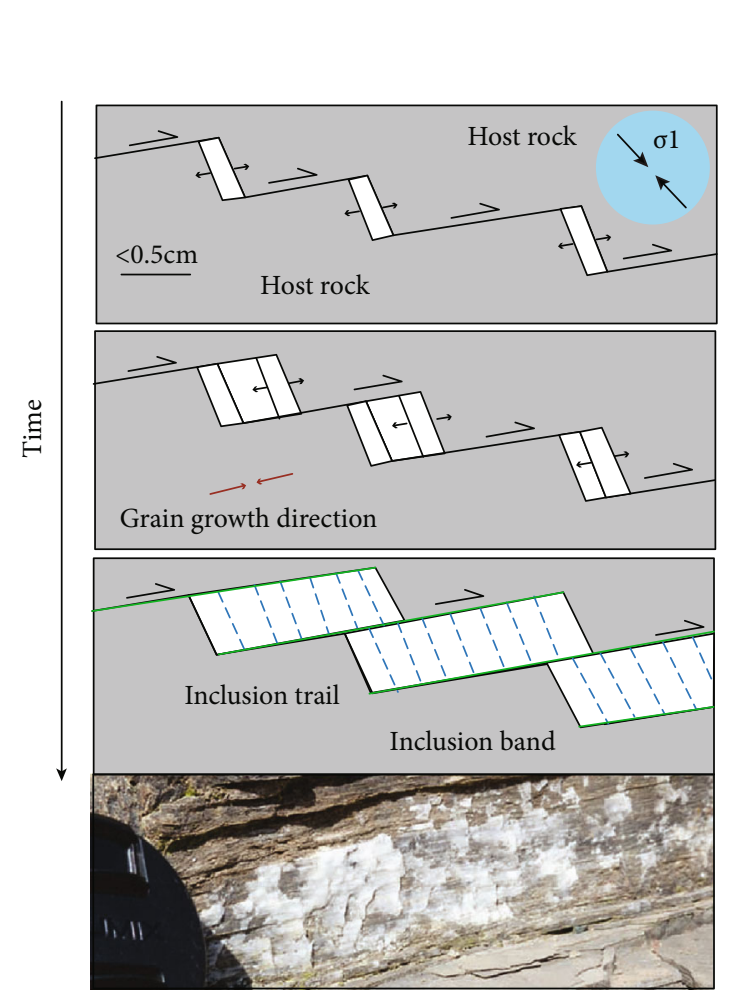

(a)
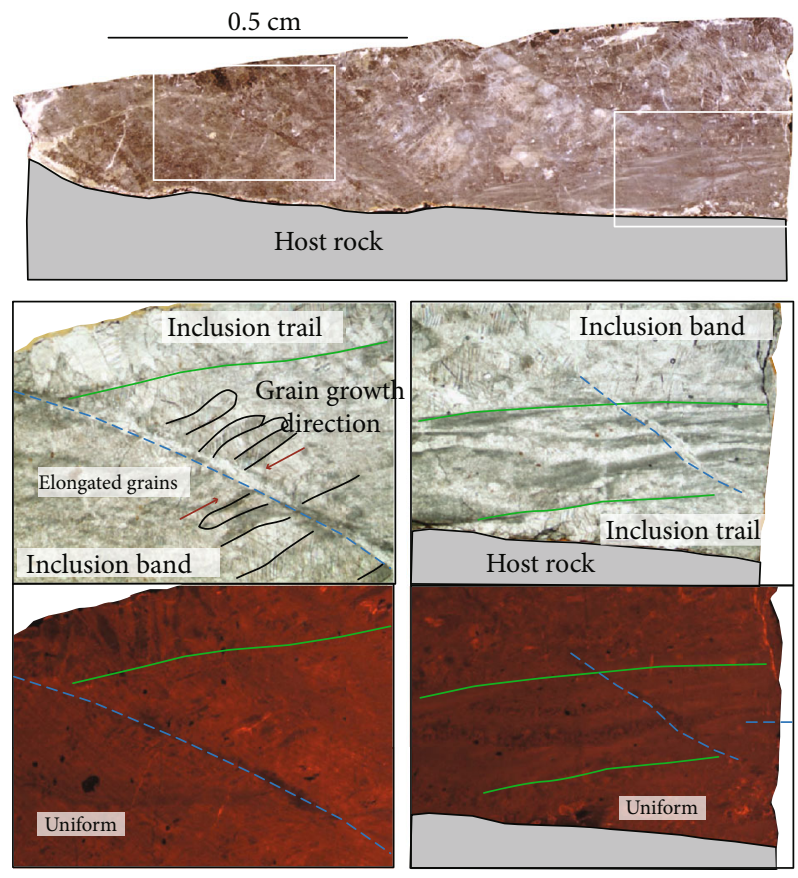

(c)
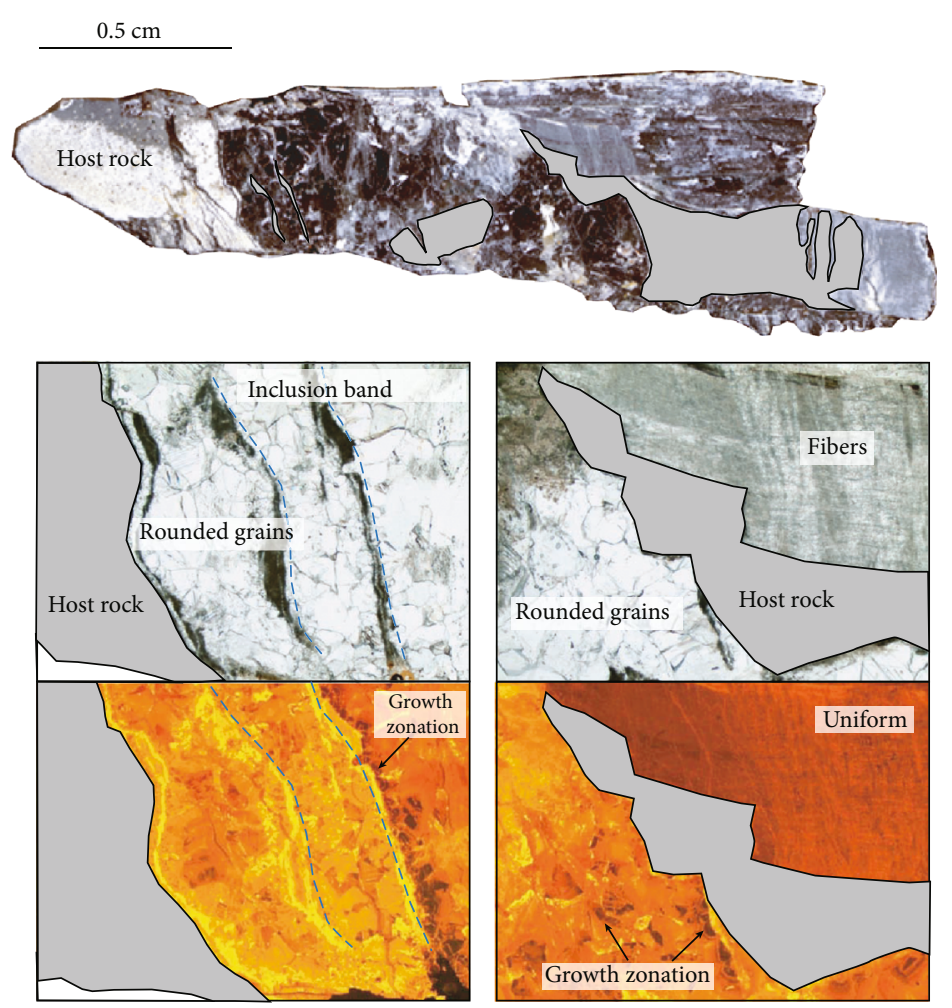

(b)
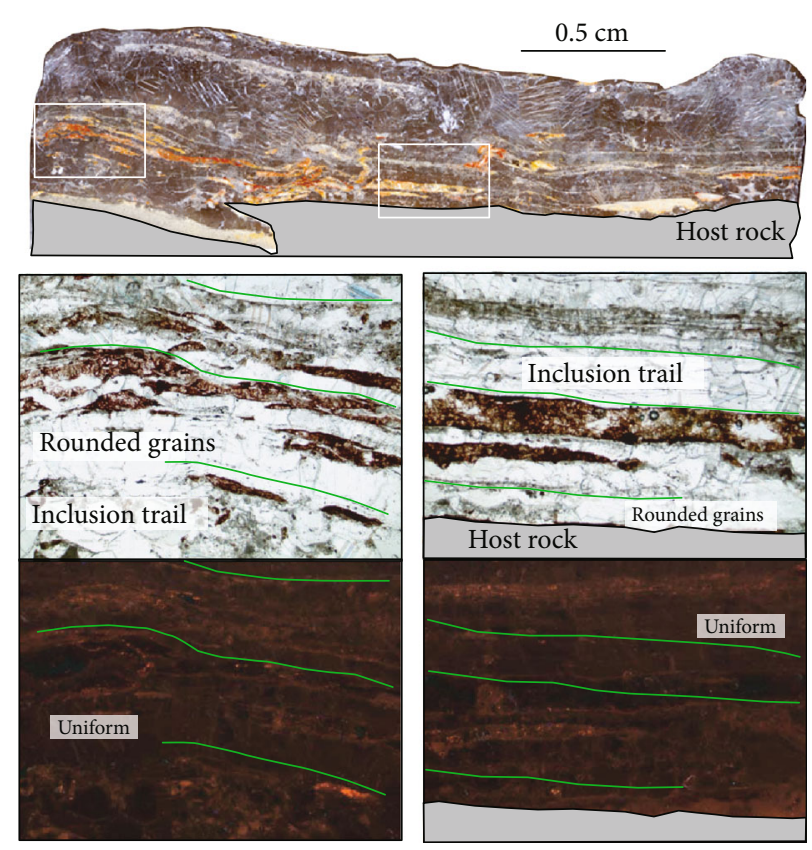

(d)

Figure 7: Petrography of the fault-related calcites (slickenfibre calcite). (a) Sketch of the slickenfibre calcite growth over time. Modified from Fagereng et al. [83]. The orientation of $\sigma 1$ is associated with the set of figures (a-d). (b) Petrography of CA18J04-3 sample. This calcite sample comes from a strike-slip fault (site 11, Figure 2) and could not be dated. Its texture is both fibrous-with a medium and uniform degree of luminescence-and granular-with the presence of growth zonations and a relatively high degree of luminescence. The inclusion bands indicate the syntectonic nature of the sample. (c) Petrography of CA18J06-1 sample (reverse fault-related calcite, Table 2). Under cathodoluminescence, calcite is uniform with a medium degree of luminescence. The presence of inclusion bands, inclusion trails, and elongated grains indicate the syntectonic nature of the sample. (d) Petrography of CA18J05-1 sample (reverse fault-related calcite, Table 2). Its texture is granular with the presence of inclusion trails, and the degree of luminescence is relatively low and uniform. 


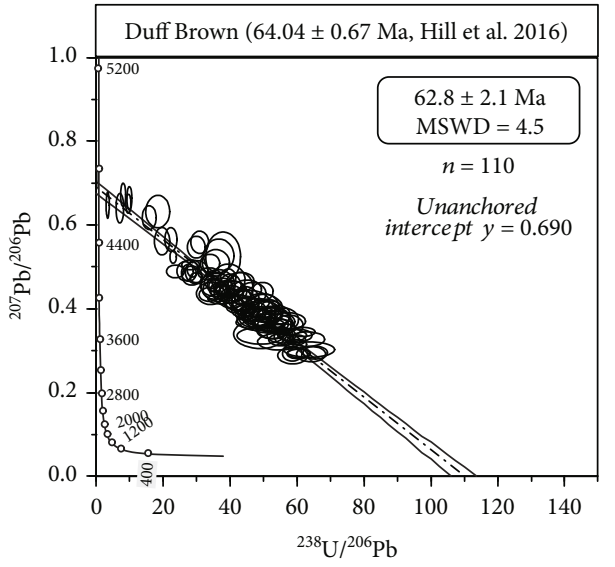

(a)

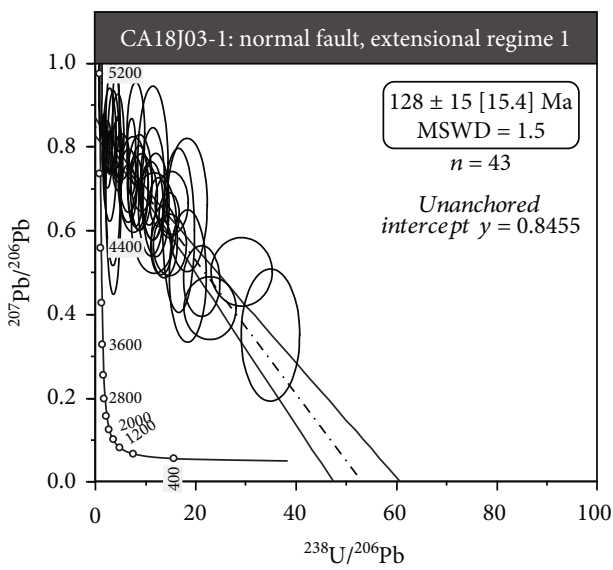

(c)

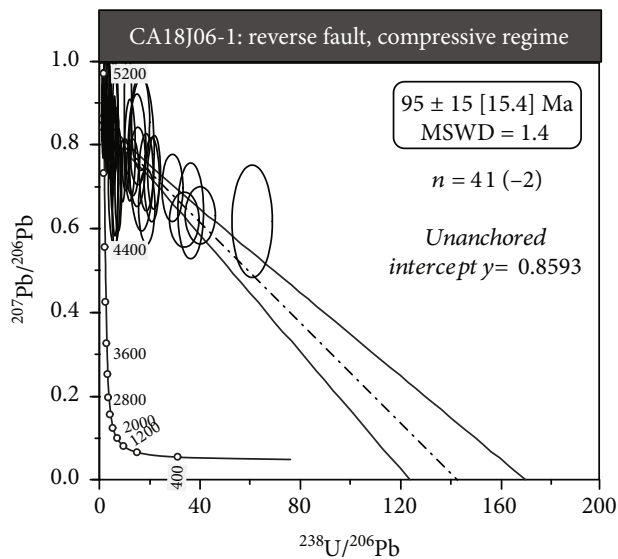

(e)

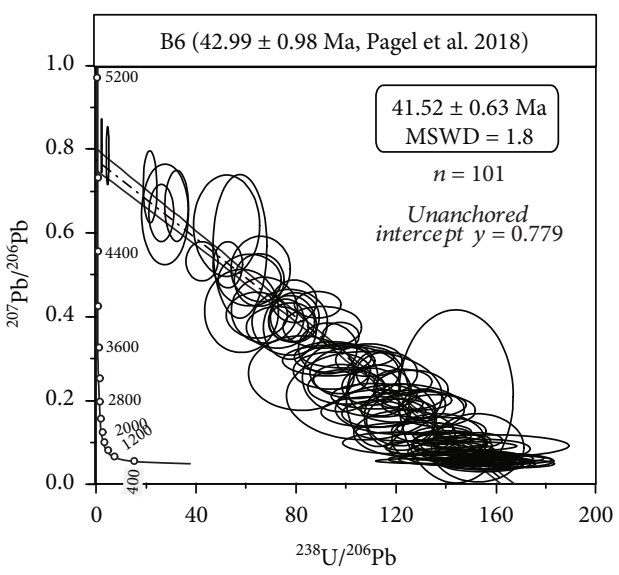

(b)

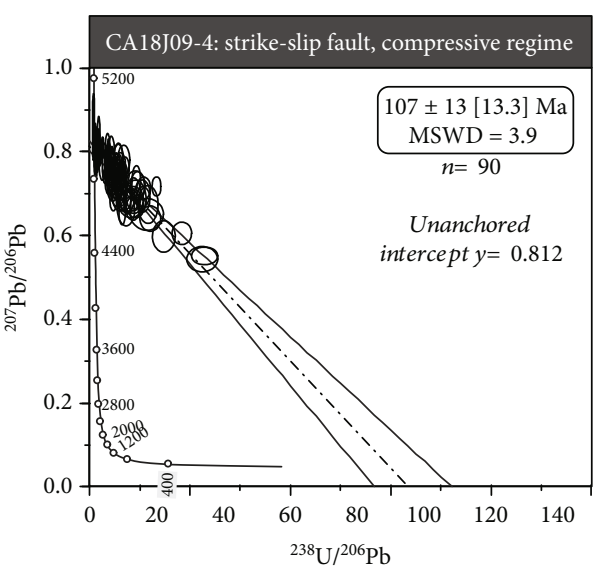

(d)

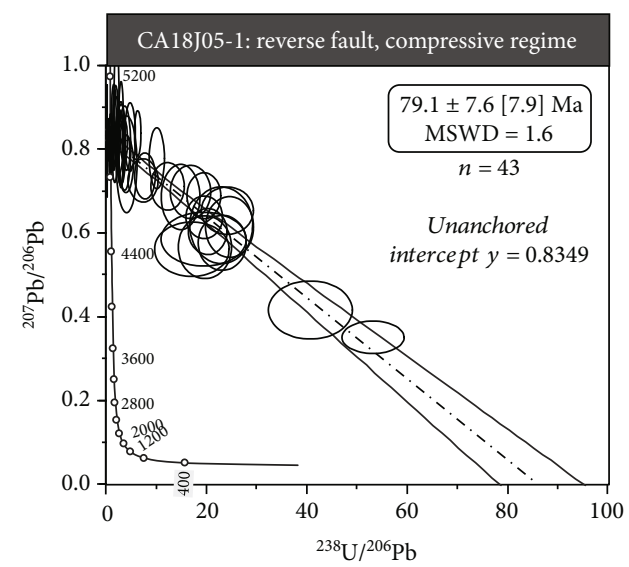

(f)

Figure 8: Continued. 


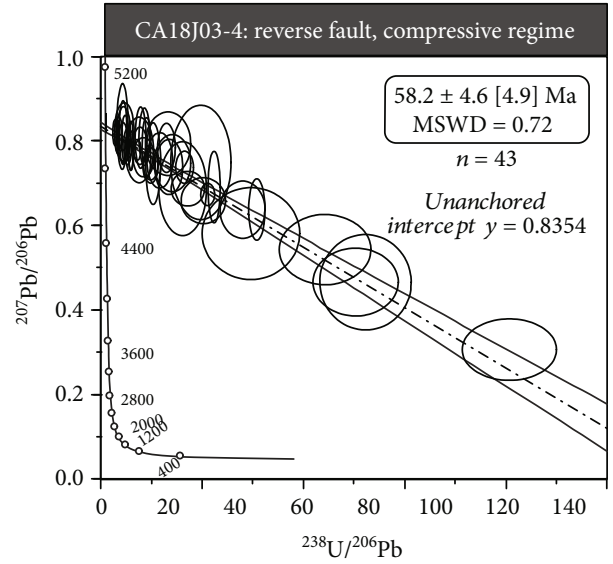

(g)

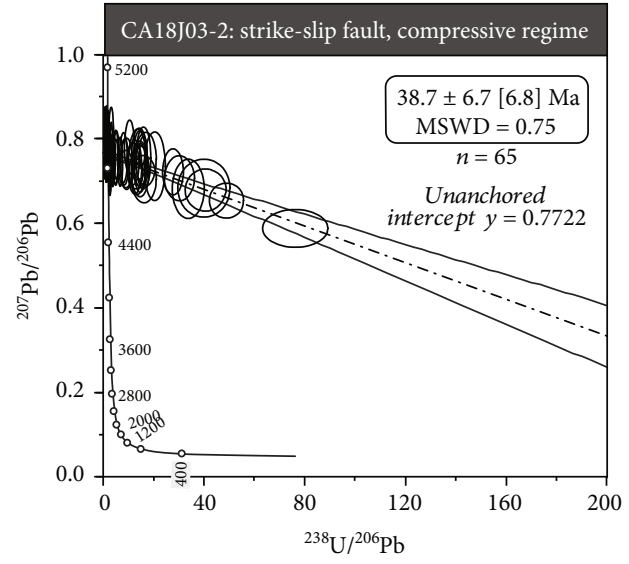

(h)

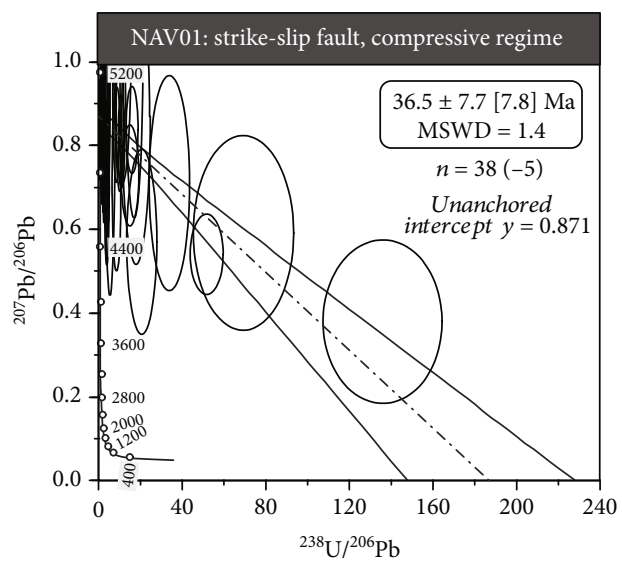

(i)

Figure 8: Tera-Wasserburg diagram $\left({ }^{207} \mathrm{~Pb} /{ }^{206} \mathrm{~Pb}\right.$ vs. $\left.{ }^{238} \mathrm{U} /{ }^{206} \mathrm{~Pb}\right)$ of the seven fault-related calcite samples dated. The uncertainties correspond to the $2 \sigma$ error and " $n$ " to the number of ablation spots performed for each sample. The numbers in parentheses correspond to the number of data removed for each T-W diagram. The uncertainties in brackets correspond to the propagated uncertainties (see Supplementary Materials for details). MSWD: mean square of weighted deviates. See Figures 5 and 6 and Table 2 for more details about the dated samples.

TABle 2: Detailed information for dated calcite samples. See Supplementary Materials for sample illustrations.

\begin{tabular}{lccc}
\hline Sample & Site & Fault & Strike/dip/pitch \\
\hline CA18J03-1 & 7 & Normal & $137^{\circ} \mathrm{N}-83^{\circ} \mathrm{N}-78^{\circ} \mathrm{W}$ \\
CA18J03-2 & 8 & Strike-slip & $120^{\circ} \mathrm{N}-89^{\circ} \mathrm{W}-5^{\circ} \mathrm{NW}$ \\
CA18J03-4 & 9 & Reverse & $175^{\circ} \mathrm{N}-30^{\circ} \mathrm{W}-\mathrm{pV} 45^{\circ}$ \\
CA18J05-1 & 14 & Reverse & $100^{\circ} \mathrm{N}-30^{\circ} \mathrm{N}-\mathrm{X}$ \\
CA18J06-1 & 17 & Reverse & $90^{\circ} \mathrm{N}-52^{\circ} \mathrm{N}-87^{\circ} \mathrm{W}$ \\
NAV01 & 21 & Strike-slip & \\
CA18J09-4 & 26 & Strike-slip & $155^{\circ} \mathrm{N}-85^{\circ} \mathrm{E}-9^{\circ} \mathrm{S}$ \\
\hline
\end{tabular}

Furthermore, reconstruction of Iberian and European plate kinematics indicates that the beginning of compression occurred around $85 \mathrm{Ma}[24,41,90]$. This value is within the uncertainties of three of the ages obtained on compressionrelated structures (sample CA18J05-1: $79.1 \pm 7.6$ [7.9] Ma, sample CA18J09-4: $107 \pm 13$ [13.3] Ma, and sample CA18J06-1: $95 \pm 15$ [15.2] Ma). As a consequence, it appears that part of the intraplate brittle deformation in the Grands Causses area also recorded the very early phases of tectonic plate convergence, probably associated with the flexuration and denudation of the lithosphere [44].

\section{Conclusion}

Until now, the lack of sedimentary records associated with deformation in the Grands Causses area has led to a poorly constrained geodynamic calendar that appeared to be controversial in various studies $[13-15,46]$. In this study, the combination of a structural study over the whole area with a petrographic and geochronological study on relatively simple objects such as fault-related calcites allows us to establish a more detailed calendar of the brittle intraplate deformation.

This study demonstrates the high sensitivity of an intraplate domain (Grands Causses area) to record deformations occurring at the edge of tectonic plates. Indeed, not only does the intraplate domain record the main relatively brief events occurring at the plate boundary such as the Eocene Pyrenean pulse, but the far-field deformation is also long and 
continuous over several tens of millions of years since the Mesozoic. The tectonic structures of the Grands Causses domain have formed in response to both the extensional deformations that occurred in Southern France (opening of the Tethys Ocean in the Jurassic, of the Pyrenean basins in the early Cretaceous, and, possibly, of the LiguroProvençal basin in the Oligocene) and also the Pyrenean compression, from the late Cretaceous to the Eocene.

Strikingly, although this domain seems to record all the geodynamic episodes that occurred in Southern France during the Meso-Cenozoic period, there is no evidence in the studied area of the closure of the Tethys Ocean and subsequent formation of the alpine belt $300 \mathrm{~km}$ to the west. Many aspects of stress transmission from plate boundaries to the intraplate domains thus still remain to be investigated, which will require a well constrained calendar of the intraplate domain deformation-a challenging task to establish.

\section{Data Availability}

The analytical and field data used to support the findings of this study are included within the article and within the supplementary information file.

\section{Conflicts of Interest}

The authors declare that they have no conflicts of interest.

\section{Acknowledgments}

The authors are grateful to Thomas Blaise and Benjamin Brigaud (GEOPS laboratory, Paris-Saclay University) for fruitful exchanges on $\mathrm{U}-\mathrm{Pb}$ calcite dating. U-Pb analyses were performed on the HR-ICPMS which is part of the PANOPLY platform (GEOPS-LSCE). O.P. benefits from a PhD Grant from the Paris-Sud University. Valérie Godard is thanked for thin-section production.

\section{Supplementary Materials}

Supplementary materials contains a sample description table as well as the detailed U-Pb method and data tables of the dating results. (Supplementary Materials)

\section{References}

[1] G. W. Lamplugh, "Structure of the Weald and analogues tracts," Quarterly Journal Geological Society, vol. 75, article LXXIII-XCV, 1920.

[2] H. Stille, Grundfragen der Vergleichenden Tektonik, Borntraeger, Berlin, 1924.

[3] K. W. Glennie and P. L. E. Boegner, "Sole pit inversion tectonics," in Petroleum Geology of the Continen-Tal Shelf of Northwest Europe, L. V. Illing and G. D. Hobson, Eds., pp. 110-120, Institute of Petroleum, London, 1981.

[4] G. D. Williams, C. M. Powell, and M. A. Cooper, "Geometry and kinematics of inversion tectonics," Geological Society, London, Special Publications, vol. 44, no. 1, pp. 3-15, 1989.
[5] F. Graveleau, J. Malavieille, and S. Dominguez, "Experimental modelling of orogenic wedges: a review," Tectonophysics, vol. 538-540, pp. 1-66, 2012.

[6] S. Cloetingh, E. Burov, and A. Poliakov, "Lithosphere folding: primary response to compression? (from Central Asia to Paris Basin)," Tectonics, vol. 18, no. 6, pp. 1064-1083, 1999.

[7] M. Gerbault, E. B. Burov, A. N. B. Poliakov, and M. Daignières, "Do faults trigger folding in the lithosphere?," Geophysical Research Letters, vol. 26, no. 2, pp. 271-274, 1999.

[8] D. Sokoutis, J.-P. Burg, M. Bonini, G. Corti, and S. Cloetingh, "Lithospheric-scale structures from the perspective of analogue continental collision," Tectonophysics, vol. 406, no. 12, pp. 1-15, 2005

[9] P. A. Ziegler, S. Cloetingh, and J.-D. van Wees, "Dynamics of intra-plate compressional deformation: the Alpine foreland and other examples," Tectonophysics, vol. 252, no. 1-4, pp. 7-59, 1995.

[10] P. Navabpour, A. Malz, J. Kley, M. Siegburg, N. Kasch, and K. Ustaszewski, "Intraplate brittle deformation and states of paleostress constrained by fault kinematics in the central German platform," Tectonophysics, vol. 694, pp. 146-163, 2017.

[11] J. Fernández-Lozano, D. Sokoutis, E. Willingshofer, S. Cloetingh, and G. De Vicente, "Cenozoic deformation of Iberia: a model for intraplate mountain building and basin development based on analogue modeling," Tectonics, vol. 30, no. 1, p. 25, 2011.

[12] R. R. Parrish, C. M. Parrish, and S. Lasalle, "Vein calcite dating reveals Pyrenean orogen as cause of Paleogene deformation in southern England," Journal of the Geological Society, vol. 175, no. 3, pp. 425-442, 2018.

[13] J. Constantin, P. Vergély, and J. Cabrera, "Tectonic evolution and related fracturing in the Causses Basin (Aveyron, France) : the Tournemire area example," Bulletin de la Societe Geologique de France, vol. 173, no. 3, pp. 229-243, 2002.

[14] O. De Charpal, P. Trémolières, F. Jean, and P. Masse, "Un exemple de tectonique de plate-forme : les causses majeurs (sud du Massif Central, France)," Revue de l'Institut Francais du Petrole, vol. 29, no. 5, pp. 641-660, 1974.

[15] J. C. Macquar, "Evolution tectonique post-hercynienne du domaine péricévenol. Incidence sur les filons de couverture. Exemple des bordures ouest et sud des Cévennes," Bulletin BRGM, vol. 1, pp. 45-68, 1973.

[16] J.-B. Peyaud, Diagenèse et transferts en milieu argileux fracturé: l'argilité de Tournemire (Aveyron, France) (Thèse de doctorat), Université Paris-Sud, France, 2002.

[17] R. Curnelle and P. Dubois, "Evolution mésozoïque des grands bassins sédimentaires français ; bassin de Paris, d'Aquitaine et du Sud-Est," Bulletin de la Societe Geologique de France, vol. 8 t.II, pp. 529-546, 1986.

[18] J. Dercourt, L. P. Zonenshain, L.-E. Ricou et al., "Geological evolution of the Tethys belt from the Atlantic to the Pamirs since the LIAS," Tectonophysics, vol. 123, no. 1-4, pp. 241$315,1986$.

[19] M. Lemoine, T. Bas, A. Arnaud-Vanneau et al., "The continental margin of the Mesozoic Tethys in the Western Alps," Marine and Petroleum Geology, vol. 3, no. 3, pp. 179-199, 1986.

[20] P. Choukroune and M. Mattauer, "Tectonique des plaques et Pyrénées ; sur le fonctionnement de la faille transformante 
nord-pyrénéenne ; comparaisons avec des modèles actuels," Bulletin de la Societe Geologique de France, vol. 5, pp. 689700, 1978.

[21] S. Jammes, G. Manatschal, L. Lavier, and E. Masini, “Tectonosedimentary evolution related to extreme crustal thinning ahead of a propagating ocean: example of the western Pyrenees," Tectonics, vol. 28, no. 4, p. 24, 2009.

[22] J. Olivet, "La cinématique de la plaque Ibérique," Bulletin des Centres de Recherches Exploration-Production Elf-Aquitaine, vol. 20, pp. 131-195, 1996.

[23] W. R. Roest and S. P. Srivastava, "Kinematics of the plate boundaries between Eurasia, Iberia, and Africa in the North Atlantic from the Late Cretaceous to the present," Geology, vol. 19, no. 6, p. 613, 1991.

[24] J.-C. Sibuet, S. P. Srivastava, and W. Spakman, "Pyrenean orogeny and plate kinematics," Journal of Geophysical Research: Solid Earth, vol. 109, no. B8, p. 18, 2004.

[25] B. Corre, Y. Lagabrielle, P. Labaume, S. Fourcade, C. Clerc, and M. Ballèvre, "Deformation associated with mantle exhumation in a distal, hot passive margin environment: new constraints from the Saraillé massif (Chaînons Béarnais, north-Pyrenean zone)," Comptes Rendus Geoscience, vol. 348, no. 3-4, pp. 279-289, 2016.

[26] G. Duée, Y. Lagabrielle, A. Coutelle, and A. Fortané, "Les lherzolites associées aux Chaînons Béarnais (Pyrénées Occidentales): mise à l'affleurement anté-dogger et resédimentation Albo-Cénomanienne," Comptes Rendus de l'Académie des Science-Series, vol. 2, no. 299, pp. 1205-1209, 1984.

[27] N. Espurt, P. Angrand, A. Teixell et al., "Crustal-scale balanced cross-section and restorations of the Central Pyrenean belt (Nestes-Cinca transect): highlighting the structural control of Variscan belt and Permian-Mesozoic rift systems on mountain building," Tectonophysics, vol. 764, pp. 25-45, 2019.

[28] J. M. Goldberg and A. F. Leyreloup, "High temperature-low pressure Cretaceous metamorphism related to crustal thinning (eastern north Pyrenean zone, France)," Contributions to Mineralogy and Petrology, vol. 104, no. 2, pp. 194-207, 1990.

[29] Y. Lagabrielle and J.-L. Bodinier, "Submarine reworking of exhumed subcontinental mantle rocks: field evidence from the Lherz peridotites, French Pyrenees," Terra Nova, vol. 20, no. 1, pp. 11-21, 2008.

[30] Y. Lagabrielle, P. Labaume, and M. de Saint Blanquat, "Mantle exhumation, crustal denudation, and gravity tectonics during Cretaceous rifting in the Pyrenean realm (SW Europe): insights from the geological setting of the lherzolite bodies," Tectonics, vol. 29, no. 4, 2010.

[31] M. Specht, Tectonique de chevauchement le long du profil ECORS-Pyrénées: un modèle d'évolution de prisme d'acrrétion continental, Université de Bretagne Occident. de Brest, 1989.

[32] A. Vacherat, F. Mouthereau, R. Pik et al., "Thermal imprint of rift-related processes in orogens as recorded in the Pyrenees," Earth and Planetary Science Letters, vol. 408, pp. 296-306, 2014.

[33] D. Vielzeuf and J. Kornprobst, "Crustal splitting and the emplacement of Pyrenean lherzolites and granulites," Earth and Planetary Science Letters, vol. 67, no. 1, pp. 87-96, 1984.

[34] E. Márton, M. C. Abranches, and J. Pais, "Iberia in the Cretaceous: new paleomagnetic results from Portugal," Journal of Geodynamics, vol. 38, no. 2, pp. 209-221, 2004.
[35] O. Lacombe, P. Laurent, and M. Rocher, "Magnitude de la contrainte déviatorique Pyrénéenne dans l'avant-pays nord Pyrénéen," Comptes rendus de l'Académie des sciences. Série 2. Sciences de la terre et des planètes, vol. 322, pp. 229-235, 1996.

[36] I. Thinon, L. Fidalgo-González, J.-P. Réhault, and J.-L. Olivet, "Déformations pyrénéennes dans le golfe de Gascogne," Comptes Rendus de l'Académie des Sciences-Series IIA-Earth and Planetary Science, vol. 332, no. 9, pp. 561-568, 2001.

[37] P.-Y. Filleaudeau, F. Mouthereau, and R. Pik, "Thermo-tectonic evolution of the south-Central Pyrenees from rifting to orogeny: insights from detrital zircon $\mathrm{U} / \mathrm{Pb}$ and (UTh)/He thermochronometry," Basin Research, vol. 24, no. 4, pp. 401-417, 2012.

[38] A. R. Grool, M. Ford, J. Vergés, R. S. Huismans, F. Christophoul, and A. Dielforder, "Insights into the crustal-scale dynamics of a doubly vergent orogen from a quantitative analysis of its forelands: a case study of the eastern Pyrenees," Tectonics, vol. 37, no. 2, pp. 450-476, 2018.

[39] J. Vergés, H. Millán, E. Roca et al., "Eastern Pyrenees and related foreland basins: pre-, syn- and post-collisional crustal-scale cross-sections," Marine and Petroleum Geology, vol. 12, no. 8, pp. 903-915, 1995.

[40] J.-C. Plaziat, "Late cretaceous to late Eocene palaeogeographic evolution of Southwest Europe," Palaeogeography, Palaeoclimatology, Palaeoecology, vol. 36, no. 3-4, pp. 263320, 1981.

[41] G. Rosenbaum, G. S. Lister, and C. Duboz, "Relative motions of Africa, Iberia and Europe during Alpine orogeny," Tectonophysics, vol. 359, no. 1-2, pp. 117-129, 2002.

[42] R. L. M. Vissers and P. T. Meijer, "Iberian plate kinematics and Alpine collision in the Pyrenees," Earth-Science Reviews, vol. 114, no. 1-2, pp. 61-83, 2012.

[43] M. Jolivet, P. Labaume, P. Monié, M. Brunel, N. Arnaud, and M. Campani, "Thermochronology constraints for the propagation sequence of the south Pyrenean basement thrust system (France-Spain)," Tectonics, vol. 26, no. 5, p. 17, 2007.

[44] S. Ternois, M. Odlum, M. Ford et al., "Thermochronological evidence of early orogenesis, Eastern Pyrenees, France," Tectonics, vol. 38, no. 4, pp. 1308-1336, 2019.

[45] F. Arthaud and P. Laurent, "Contraintes, déformation et déplacement dans $\Gamma$ avant-pays Nord-pyrénéen du Languedoc méditerranéen," Geodinamica Acta, vol. 8, no. 3, pp. 142-157, 2015.

[46] J. L. Blés, D. Bonijoly, C. Castaing, and Y. Gros, "Successive post-Variscan stress fields in the French Massif Central and its borders (Western European plate): comparison with geodynamic data," Tectonophysics, vol. 169, no. 1-3, pp. 79111, 1989.

[47] F. Christophoul, J.-C. Soula, S. Brusset et al., "Time, place and mode of propagation of foreland basin systems as recorded by the sedimentary fill: examples of the Late Cretaceous and Eocene retro-foreland basins of the north-eastern Pyrenees," Geological Society, London, Special Publications, vol. 208, no. 1, pp. 229-252, 2003.

[48] P. Souquet and J. Deramond, "Séquence de chevauchements et séquences de dépôt dans un bassin d'avant-fosse. Exemple du sillon crétacé du versant sud des Pyrénées (Espagne)," Comptes Rendus de l'Académie des Sciences-Series II-Mécanique, Physique, Chimie, Sciences de l'univers, Sciences de la Terre, vol. 309, pp. 137-144, 1989. 
[49] S. Leleu, J.-F. Ghienne, and G. Manatschal, "Alluvial fan development and morpho-tectonic evolution in response to contractional fault reactivation (Late Cretaceous-Palaeocene), Provence, France," Basin Research, vol. 21, no. 2, pp. 157-187, 2009.

[50] J. P. Platel, "Stratigraphie, sédimentologie et évolution géodynamique de la plate-forme carbonatée du Crétacé supérieure du nord du bassin d'Aquitaine," Géologie de la France, vol. 4, pp. 33-58, 1996.

[51] J.-P. Gély and K. Sztràkos, "L'évolution paléogéographique et géodynamique du Bassin aquitain au Paléogène : enregistrement et datation de la tectonique pyrénéenne," Géologie de la France, vol. 2, pp. 31-57, 2000.

[52] A. Ortiz, F. Guillocheau, E. Lasseur et al., "Sediment routing system and sink preservation during the post-orogenic evolution of a retro-foreland basin: the case example of the North Pyrenean (Aquitaine, Bay of Biscay) basins," Marine and Petroleum Geology, vol. 112, article 104085, 2020.

[53] J. Briais, F. Guillocheau, E. Lasseur, C. Robin, J. J. Châteauneuf, and O. Serrano, "Response of a low-subsiding intracratonic basin to long wavelength deformations: the Palaeoceneearly Eocene period in the Paris Basin," Solid Earth, vol. 7, no. 1, pp. 205-228, 2016.

[54] J. Barbarand, F. Quesnel, and M. Pagel, "Lower Paleogene denudation of Upper Cretaceous cover of the Morvan massif and southeastern Paris Basin (France) revealed by AFT thermochronology and constrained by stratigraphy and paleosurfaces," Tectonophysics, vol. 608, pp. 1310-1327, 2013.

[55] X. Le Pichon, G. Pautot, J.-M. Auzende, and J.-L. Olivet, "La Mediterranee Occidentale depuis l'Oligocene Schema d'evolution," Earth and Planetary Science Letters, vol. 13, no. 1, pp. 145-152, 1971.

[56] M. Séranne, "The Gulf of Lion continental margin (NW Mediterranean) revisited by IBS: an overview," Geological Society, London, Special Publications, vol. 156, no. 1, pp. 1536, 1999.

[57] J.-P. Rehault, G. Boillot, and A. Mauffret, “The Western Mediterranean Basin geological evolution," Marine Geology, vol. 55, no. 3-4, pp. 447-477, 1984.

[58] M. Séranne, A. Benedicto, P. Labaum, C. Truffert, and G. Pascal, "Structural style and evolution of the Gulf of Lion Oligo-Miocene rifting: role of the Pyrenean orogeny," Marine and Petroleum Geology, vol. 12, no. 8, pp. 809-820, 1995.

[59] E. Sanchis and M. Séranne, "Structural style and tectonic evolution of a polyphase extensional basin of the Gulf of Lion passive margin: the Tertiary Alès basin, southern France," Tectonophysics, vol. 322, no. 3-4, pp. 219-242, 2000.

[60] L. Jolivet, C. Gorini, J. Smit, and S. Leroy, "Continental breakup and the dynamics of rifting in back-arc basins: the Gulf of Lion margin," Tectonics, vol. 34, no. 4, pp. 662-679, 2015.

[61] M. Lopez, Dynamique du passage d'un appareil terrigène à une plate-forme carbonatée en domaine semi-aride: le Trias de Lodève, sud de la France, Université Montpellier II, 1992.

[62] L. Bruxelles, P. Amben, J.-L. Guendon, and G. Tronchetti, "Les affleurements de Crétacé supérieur sur les Grands Causses méridionaux (France)," Comptes Rendus de l'Académie des Sciences-Series IIA-Earth and Planetary Science, vol. 329, no. 10, pp. 705-712, 1999.

[63] D. Bonijoly, J. Perrin, F. Roure et al., "The Ardèche palaeomargin of the South-East Basin of France: Mesozoic evolu- tion of a part of the Tethyan continental margin (Géologie Profonde de la France programme)," Marine and Petroleum Geology, vol. 13, no. 6, pp. 607-623, 1996.

[64] P. Charcosset, "Synthèse paléogéographique et dynamique du bassin caussenard (Sud de la France) au cours du Bathonien (Jurassique moyen)," Eclogae Geologicae Helvetiae, vol. 93, pp. 53-64, 2000.

[65] T. Dumont, "Late Triassic-early Jurassic evolution of the western Alps and of their European foreland; initiation of the Tethyan rifting," Bulletin de la Societe Geologique de France, vol. 8 t. IV, pp. 601-611, 1999.

[66] F. Arthaud and M. Séguret, "Les structures pyreneennes du Languedoc et du Golfe du Lion (Sud de la France)," Bulletin de la Societe Geologique de France, vol. S7-XXIII, no. 1, pp. 51-63, 1981.

[67] H. Camus, "Formation des réseaux karstiques et creusement des vallées: l'exemple du Larzac méridional, Hérault, France," Karstologia, vol. 29, no. 1, pp. 23-42, 1997.

[68] L. Bruxelles, "Reconstitution morphologique du Causse du Larzac : rôle des formations superficielles dans la morphogenèse karstique," Karstologia, vol. 38, pp. 25-40, 2002.

[69] E. Husson, Interaction géodynamique/karstification et modélisation géologique $3 D$ des massifs carbonatés: Implication sur la distribution prévisionnelle de la karstification. Exemple des paléokarts crétacés à néogènes du Languedoc montpelliérain, Université Montpellier II, 2014.

[70] J. Barbarand, F. Lucazeau, M. Pagel, and M. Seranne, "Burial and exhumation history of the south-eastern Massif Central (France) constrained by apatite fission-track thermochronology," Tectonophysics, vol. 335, no. 3-4, pp. 275-290, 2001.

[71] J.-B. Peyaud, J. Barbarand, A. Carter, and M. Pagel, "MidCretaceous uplift and erosion on the northern margin of the Ligurian Tethys deduced from thermal history reconstruction," International Journal of Earth Sciences, vol. 94, no. 3, pp. 462-474, 2005.

[72] M. Séranne, H. Camus, F. Lucazeau, J. Barbarand, and Y. Quinif, "Surrection et érosion polyphasées de la bordure cévenole. Un exemple de morphogenèse lente," Bulletin de la Societe Geologique de France, vol. 173, pp. 97-112, 2002.

[73] D. Delvaux and B. Sperner, "New aspects of tectonic stress inversion with reference to the tensor program," Geological Society, London, Special Publications, vol. 212, no. 1, pp. 75100, 2003.

[74] J. Angelier and P. Mechler, "Sur une methode graphique de recherche des contraintes principales egalement utilisables en tectonique et en seismologie : la methode des diedres droits," Bulletin de la Société Géologique de France, vol. S7XIX, no. 6, pp. 1309-1318, 1977.

[75] N. M. W. Roberts, E. T. Rasbury, R. R. Parrish, C. J. Smith, M. S. A. Horstwood, and D. J. Condon, "A calcite reference material for LA-ICP-MS U-Pb geochronology," Geochemistry, Geophysics, Geosystems, vol. 18, no. 7, pp. 2807-2814, 2017.

[76] C. A. Hill, V. J. Polyak, Y. Asmerom, and P. Provencio, "Constraints on a Late Cretaceous uplift, denudation, and incision of the Grand Canyon region, southwestern Colorado Plateau, USA, from U-Pb dating of lacustrine LIMESTONE," Tectonics, vol. 35, no. 4, pp. 896-906, 2016.

[77] M. Pagel, M. Bonifacie, D. A. Schneider et al., "Improving paleohydrological and diagenetic reconstructions in calcite veins and breccia of a sedimentary basin by combining $\Delta 47$ 
temperature, $\delta 18$ Owater and U-Pb age," Chemical Geology, vol. 481, pp. 1-17, 2018.

[78] C. Paton, J. Hellstrom, B. Paul, J. Woodhead, and J. Hergt, "Iolite: freeware for the visualisation and processing of mass spectrometric data," Journal of Analytical Atomic Spectrometry, vol. 26, no. 12, pp. 2508-2518, 2011.

[79] F. Tera and G. J. Wasserburg, "U-Th-Pb systematics in three Apollo 14 basalts and the problem of initial $\mathrm{Pb}$ in lunar rocks," Earth and Planetary Science Letters, vol. 14, no. 3, pp. 281-304, 1972.

[80] K. R. Ludwig, ISOPLOT: a plotting and regression program for radiogenic-isotope data; version 4.15, US Geological Survey, Reston, VA, 1991.

[81] J. G. Ramsay and M. I. Huber, The Techniques of Modern Structural Geology, Volume 1, Basic Techniques-Strain Analysis, Academic Press, London, 1983.

[82] D. Koehn and C. W. Passchier, "Shear sense indicators in striped bedding-veins," Journal of Structural Geology, vol. 22, no. 8, pp. 1141-1151, 2000.

[83] Å. Fagereng, F. Remitti, and R. H. Sibson, "Shear veins observed within anisotropic fabric at high angles to the maximum compressive stress," Nature Geoscience, vol. 3, no. 7, pp. 482-485, 2010.

[84] P. D. Bons, M. A. Elburg, and E. Gomez-Rivas, "A review of the formation of tectonic veins and their microstructures," Journal of Structural Geology, vol. 43, pp. 33-62, 2012.

[85] Å. Fagereng, F. Remitti, and R. H. Sibson, "Incrementally developed slickenfibers - geological record of repeating low stress-drop seismic events?," Tectonophysics, vol. 510, no. 3-4, pp. 381-386, 2011.

[86] J. F. Gamond, "Displacement features associated with fault zones: a comparison between observed examples and experimental models," Journal of Structural Geology, vol. 5, no. 1, pp. 33-45, 1983.

[87] L. Smeraglia, S. M. Bernasconi, F. Berra et al., "Crustalscale fluid circulation and co-seismic shallow combveining along the longest normal fault of the central Apennines, Italy," Earth and Planetary Science Letters, vol. 498, pp. 152-168, 2018.

[88] J. Mencos, N. Carrera, and J. A. Muñoz, "Influence of rift basin geometry on the subsequent postrift sedimentation and basin inversion: the Organyà Basin and the Bóixols thrust sheet (south central Pyrenees)," Tectonics, vol. 34, no. 7, pp. 1452-1474, 2015.

[89] J. Tugend, G. Manatschal, N. J. Kusznir, E. Masini, G. Mohn, and I. Thinon, "Formation and deformation of hyperextended rift systems: insights from rift domain mapping in the Bay of Biscay-Pyrenees," Tectonics, vol. 33, no. 7, pp. 1239-1276, 2014.

[90] M. R. Handy, M. Schmid, R. Bousquet, E. Kissling, and D. Bernoulli, "Reconciling plate-tectonic reconstructions of Alpine Tethys with the geological-geophysical record of spreading and subduction in the Alps," Earth-Science Reviews, vol. 102, no. 3-4, pp. 121-158, 2010.

[91] B. Alabouvette, Carte géologique de la France, feuille 887: Génolhac, BRGM, 1988, 1/50 000.

[92] B. Alabouvette, Carte géologique de la France, feuille 989: Lodève, BRGM, 1982, 1/50 000.

[93] B. Alabouvette, F. Arthaud, Y. Bodeur et al., Carte géologique de la France, feuille 997: Le Vigan, BRGM, 1988, 1/50 000.
[94] B. Alabouvette, Y. Bodeur, J. Mattei, M. Lopez, J. P. Rançon, and H. Paloc, Carte géologique de la France, feuille 962: Le Caylar, BRGM, 1987, 1/50 000.

[95] B. Alabouvette, J.-P. Burg, C. Delor et al., Carte géologique de la France, feuille 884: Rodez, BRGM, 1988, 1/50 000.

[96] S. Bogdanoff, M. Donnot, and F. Ellenberger, Carte géologique de la France, feuille 988: Bédarieux, BRGM, 1984, $1 / 50000$.

[97] B. Briand, C. Legendre, J. Y. Prax et al., Carte géologique de la France, feuille 861: Saint-Geniez d'Olt, BRGM, 2009, $1 / 50000$.

[98] B. Briand, J. Negron, M. Viard, R. Combemorel, and J. P. Couturie, Carte géologique de la France, feuille 863: Le Bleymard, BRGM, 1994, 1/50 000.

[99] B. Briand, G. Peyretti, and J. P. Couturie, Carte géologique de la France, feuille 862: Mende, BRGM, 1979, 1/50 000.

[100] P. Brouder, B. Alabouvette, and M. Faure, Carte géologique de la France, feuille 911: Saint-Andre-de-Valborgne, BRGM, 2009, 1/50 000 .

[101] J.-P. Burg, A. F. Leyreloup, C. Delor, and C. Teyssier, Carte géologique de la France, feuille 908: Salles-Curan, BRGM, 1989, 1/50 000.

[102] B. Defaut, J.-P. Burg, A. F. Leyreloup, A. Boitaut, and F. Romney, Carte géologique de la France, feuille 885: Sévérac-le-Château, BRGM, 1990, 1/50 000.

[103] M. Demange, J. Guérangé-Lozes, and B. Guérangé, Carte géologique de la France, feuille 987: Lacaune, BRGM, $1996,1 / 50000$.

[104] M. Donnot, A. Lefavrais, G. Lablanche, C. Greber, J. M. Rouchy, and J. P. Prian, Carte géologique de la France, feuille 961: Camarès, BRGM, 1990, 1/50 000.

[105] B. Geze, J. C. L. Macquar, J. G. Michaud, M. Rey, and P. Brouder, Carte géologique de la France, feuille 910: Meyrueis, BRGM, 1977, 1/50 000.

[106] B. Geze and H. Paloc, Carte géologique de la France, feuille 936: Nant, BRGM, 1986, 1/50 000.

[107] B. Geze, J. Pellet, and H. Paloc, Carte géologique de la France, feuille 886: Florac, BRGM, 1980, 1/50 000.

[108] J. Guérangé-Lozes and B. Alabouvette, Carte géologique de la France, feuille 960: Saint-Sernin-sur-Rance, BRGM, 1999, $1 / 50000$.

[109] J. Guérangé-Lozes, J.-P. Burg, C. Vinchon, B. Defaut, and B. Alabouvette, Carte géologique de la France, feuille 934: Réquista, BRGM, 1996, 1/50 000.

[110] M. Mattauer, Carte géologique de la France, feuille 990: Montpellier, BRGM, 1967, 1/50 000.

[111] G. Mennessier and P. Collomb, Carte géologique de la France, feuille 909: Saint-Beauzély, BRGM, 1986, 1/50 000.

[112] G. Mennessier and P. Collomb, Carte géologique de la France, feuille 935: Millau, BRGM, 1983, 1/50 000.

[113] H. Philip, M. Mattauer, Y. Bodeur, M. Seguret, J. P. Puech, and J. Mattei, Carte géologique de la France, feuille 963: Saint-Martin-de-Londres, BRGM, 1978, 1/50 000.

[114] C. Rousset, P. Arlhac, and J. F. Becq-Giraudon, Carte géologique de la France, feuille 860: Espalion, BRGM, 1989, $1 / 50000$.

[115] C. Beaumont, J. A. Muñoz, J. Hamilton, and P. Fullsack, "Factors controlling the Alpine evolution of the Central Pyrenees inferred from a comparison of observations and 
geodynamical models," Journal of Geophysical Research: Solid Earth, vol. 105, no. B4, pp. 8121-8145, 2000.

[116] P.-Y. Filleaudeau, Croissance et dénudation des Pyrénées du Crétacé supérieur au Paléogène: apports de l'analyse de bassin et thermochronométrie détritique, UPMC, 2011.

[117] A. Teixell, "Crustal structure and orogenic material budget in the west Central Pyrenees," Tectonics, vol. 17, no. 3, pp. 395406, 1998.

[118] J. Tugend, G. Manatschal, N. J. Kusznir, and E. Masini, "Characterizing and identifying structural domains at rifted continental margins: application to the Bay of Biscay margins and its Western Pyrenean fossil remnants," Geological Society, London, Special Publications, vol. 413, no. 1, pp. 171203, 2015. 